\title{
Reactive and organic halogen species in three different European coastal environments
}

\author{
C. Peters ${ }^{1}$, S. Pechtt ${ }^{1}$, J. Stutz ${ }^{3}$, K. Hebestreit ${ }^{1}$, G. Hönninger ${ }^{1}$, K. G. Heumann ${ }^{2}$, A. Schwarz ${ }^{2}$, J. Winterlik ${ }^{2}$, and \\ U. Platt ${ }^{1}$ \\ ${ }^{1}$ Institute for Environmental Physics, University of Heidelberg, Im Neuenheimer Feld 229, 69120 Heidelberg, Germany \\ ${ }^{2}$ Institute for Inorganic and Analytical Chemistry, University of Mainz, Düsbergweg 10-14, 55099 Mainz, Germany \\ ${ }^{3}$ Dept. of Atmospheric and Oceanic Sciences, UCLA, 7127 Math Sciences Los Angeles, CA 90095-1565, USA
}

Received: 7 June 2005 - Published in Atmos. Chem. Phys. Discuss.: 17 August 2005

Revised: 17 November 2005 - Accepted: 18 November 2005 - Published: 15 December 2005

\begin{abstract}
We present results of three field campaigns using active longpath DOAS (Differential Optical Absorption Spectroscopy) for the study of reactive halogen species (RHS) $\mathrm{BrO}, \mathrm{IO}, \mathrm{OIO}$ and $\mathrm{I}_{2}$. Two recent field campaigns took place in Spring 2002 in Dagebüll at the German North Sea Coast and in Spring 2003 in Lilia at the French Atlantic Coast of Brittany. In addition, data from a campaign in Mace Head, Ireland in 1998 was partly re-evaluated. During the recent field campaigns volatile halogenated organic compounds (VHOCs) were determined by a capillary gas chromatograph coupled with an electron capture detector and an inductively coupled plasma mass spectrometer (GC/ECD-ICPMS) in air and water. Due to the inhomogeneous distribution of macroalgae at the German North Sea Coast we found a clear connection between elevated levels of VHOCs and the appearance of macroalgae. Extraordinarily high concentrations of several VHOCs, especially $\mathrm{CH}_{3} \mathrm{I}$ and $\mathrm{CH}_{3} \mathrm{Br}$ of up to 1830 pptv and 875 pptv, respectively, were observed at the coast of Brittany, demonstrating the outstanding level of bioactivity there. We found $\mathrm{CH}_{2} \mathrm{I}_{2}$ at levels of up to $20 \mathrm{pptv}$, and a clear anti-correlation with the appearance of IO. The IO mixing ratio reached up to $7.7 \pm 0.5 \mathrm{ppt}$ ( $\mathrm{pmol} / \mathrm{mol}$ ) during the day, in reasonable agreement with model studies designed to represent the meteorological and chemical conditions in Brittany. For the two recent campaigns the DOAS spectra were evaluated for $\mathrm{BrO}$, $\mathrm{OIO}$ and $\mathrm{I}_{2}$, but none of these species could be clearly identified (average detection limits around $2 \mathrm{ppt}, 3 \mathrm{ppt}, 20 \mathrm{ppt}$, resp., significantly higher in individual cases). Only in the Mace Head spectra evidence was found for the presence of OIO. Since macroalgae under oxidative stress are suggested to be a further source for $I_{2}$ in the marine boundary layer, we re-analyzed spectra in the $500-600 \mathrm{~nm}$ range taken during the 1998 PARFORCE campaign in Mace Head, Ireland,
\end{abstract}

Correspondence to: C. Peters

(christina.peters@iup.uni-heidelberg.de) which had not previously been analyzed for $\mathrm{I}_{2}$. We identified molecular iodine above the detection limit ( $20 \mathrm{ppt})$, with peak mixing ratios of $61 \pm 12$ ppt. Since $I_{2}$ was undetectable during the Brittany campaign, we suggest that iodine may not be released into the atmosphere by macroalgae in general, but only by a special type of the laminaria species under oxidative stress. Only during periods of extraordinarily low water (spring-tide), the plant is exposed to ambient air and may release gaseous iodine in some way to the atmosphere. The results of our re-analysis of spectra from the PARFORCE campaign in 1998 support this theory. Hence, we feel that we can provide an explanation for the different $I_{2}$ levels in Brittany and Mace Head.

\section{Introduction}

It is well established that RHS significantly influence a variety of atmospheric processes. This is impressively demonstrated during polar spring, when boundary layer ozone is depleted within days or even hours by catalytic cycles involving bromine, the so-called "bromine explosion" events (e.g. Platt and Lehrer, 1996). The presence of halogen oxides outside polar regions could influence the ozone budget as well as the oxidation capacity of the troposphere by catalytic destruction via $\mathrm{X}+\mathrm{O}_{3}$ and by affecting the $\mathrm{NO} / \mathrm{NO}_{2}$ and $\mathrm{OH} / \mathrm{HO}_{2}$ partitioning (e.g. Platt and Hönninger, 2003). On local scales the presence of $\mathrm{BrO}$ in mid-latitudinal regions has been observed thus far in a variety of different environments, e.g. salt lakes (Hebestreit et al., 1999; Stutz et al., 2002; Hönninger et al., 2004b; Zingler and Platt, 2005) and volcanic plumes (Bobrowski et al., 2003) as well as in the marine boundary layer (Leser et al., 2003; Saiz-Lopez et al., 2004a). Significant appearance of reactive iodine species (IO, OIO, $\mathrm{I}_{2}$ ) has thus far been reported primarily from coastal sites. An overview of the hitherto detected mixing ratios of RHS in the lower troposphere is given in Table 1. IO could contribute to

(C) 2005 Author(s). This work is licensed under a Creative Commons License. 
Table 1. Observation of RHS in the troposphere by the active and passive DOAS technique.

\begin{tabular}{|c|c|c|c|c|}
\hline Spec. & Location, year & Max. Conc. [ppt] & Error $\pm(2 \sigma)[\mathrm{ppt}]$ & Reference \\
\hline IO & Mace Head, Ireland (1997) & 6.7 & 0.5 & Alicke et al. (1999) \\
\hline IO & Mace Head (1998) & 7.2 & 0.3 & Hebestreit (2001) \\
\hline IO & Mace Head (2002) & 7 & 0.5 & Saiz-Lopez and Plane (2004) \\
\hline IO & Tasmania (1999) & 2.2 & 0.4 & Allan et al. (2000) \\
\hline IO & Tenerife, Can. Islands (1997) & 3.5 & 0.4 & Allan et al. (2000) \\
\hline IO & Kerguelen, Ind. Ocean (2002) & $\leq$ D.L. $(1.4)$ & 1.4 & Sebastián (2004) \\
\hline IO & North Sea, Germany (2002) & 2.1 & 0.5 & this work \\
\hline IO & Atlantic Coast, France (2003) & 7.7 & 0.5 & this work \\
\hline IO & Crete, Greece (2003) & $\leq$ D.L. $(0.8)$ & 0.8 & Hönninger (2002) \\
\hline IO & Dead Sea, Israel (2000) & 10 & 2.4 & Zingler and Platt (2005) \\
\hline IO & Antarctic and Arctic & 10 & - & Frieß et al. (2001), Wittrock et al. (2000) \\
\hline IO & Alert, Arctic (2000) & 0.73 & 0.23 & Hönninger (2002) \\
\hline OIO & Cape Grim, Tasmania (1999) & $3.0^{\mathrm{a}}$ & 0.5 & Allan et al. (2001) \\
\hline OIO & Mace Head, Ireland (1998) & $9.2^{\mathrm{b}}$ & 3.3 & this work \\
\hline OIO & Mace Head, Ireland (2002) & $3.0^{\mathrm{a}}$ & 0.5 & Saiz-Lopez and Plane (2004) \\
\hline $\mathrm{I}_{2}$ & Mace Head, Ireland (2002) & 93 & 3 & Saiz-Lopez and Plane (2004) \\
\hline $\mathrm{I}_{2}$ & Mace Head, Ireland (1998) & 61.3 & 12 & this work \\
\hline $\mathrm{I}_{2}$ & Atlantic Coast, France (2003) & $\leq$ D.L. $(10.15)$ & 10.15 & this work \\
\hline $\mathrm{BrO}$ & Mid.Lat. MBL & 6.0 & - & Leser et al. (2003), Saiz-Lopez et al. (2004a) \\
\hline $\mathrm{BrO}$ & $\begin{array}{l}\text { Salt lakes (Dead Sea, } \\
\text { Salt Lake City, Caspian Sea, } \\
\text { Salar de Uyuni) }\end{array}$ & $\leq 176$ & - & $\begin{array}{l}\text { Hebestreit et al. (1999), Matveev et al. (2001), } \\
\text { Wagner et al. (2001), Stutz et al. (2002), } \\
\text { Hönninger et al. (2004a) }\end{array}$ \\
\hline $\mathrm{BrO}$ & Antarctic, Arctic & 30 & - & $\begin{array}{l}\text { Hausmann and Platt (1994), Tuckermann et al. (1997), } \\
\text { Hegels et al. (1998), Martinez et al. (1999), } \\
\text { Hönninger et al. (2004b), Frieß (2001) }\end{array}$ \\
\hline $\mathrm{BrO}$ & Volcanoes & $\sim 1000$ & - & Bobrowski et al. (2003) \\
\hline
\end{tabular}

${ }^{\mathrm{a}} \sigma_{\mathrm{OIO}}(548.6 \mathrm{~nm})=6.8 \times 10^{-17} \mathrm{~cm}^{2}($ Cox et al., 1999$)$

$\mathrm{b}_{\sigma_{\mathrm{OIO}}}(548.6 \mathrm{~nm})=1.1 \times 10^{-17} \mathrm{~cm}^{2}$ (Bloss et al., 2001)

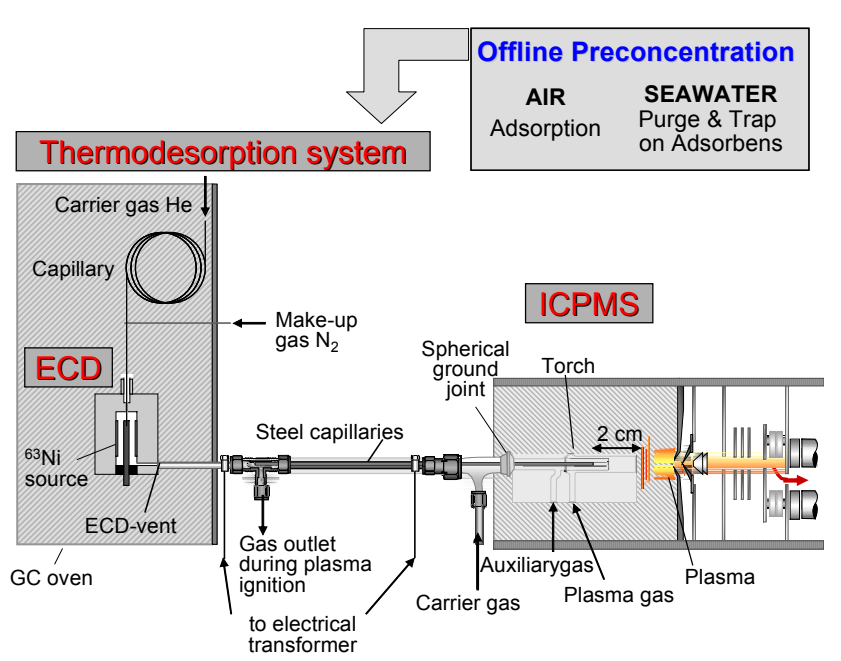

Fig. 1. Schematic overview of the GC/ECD-ICPMS, which is a highly sensitive detection method for halogenated hydrocarbons. ozone destruction in a manner comparable to $\mathrm{BrO}$, even in low mixing ratios. Additionally, recent field and laboratory studies indicate that reactive iodine plays an important role in new particle formation processes (Hoffmann et al., 2001; O'Dowd et al., 2002; Jimenez et al., 2003; Burkholder et al., 2004). Instances of particle formation, with concentrations of up to $10^{6}$ particles $/ \mathrm{cm}^{3}$, have been observed in marine environments (e.g. O’Dowd et al., 1998; Mäkelä et al., 2002). As particles in the marine atmosphere affect the microphysical properties of stratocumulus clouds, they potentially have an impact on climate. Therefore the investigation of sources, appearance, and distribution of reactive iodine species on a global scale is of high interest in present research activities.

The current understanding of the particle formation process is quite limited. O'Dowd et al. (2002) proposed that particle formation in coastal environments is dominated by polymerization of the OIO radical. However, field observations of OIO in the marine environment are rare (Allan et al., 2000), even though great effort was made for its detection. These measurements, as well as observations presented in 


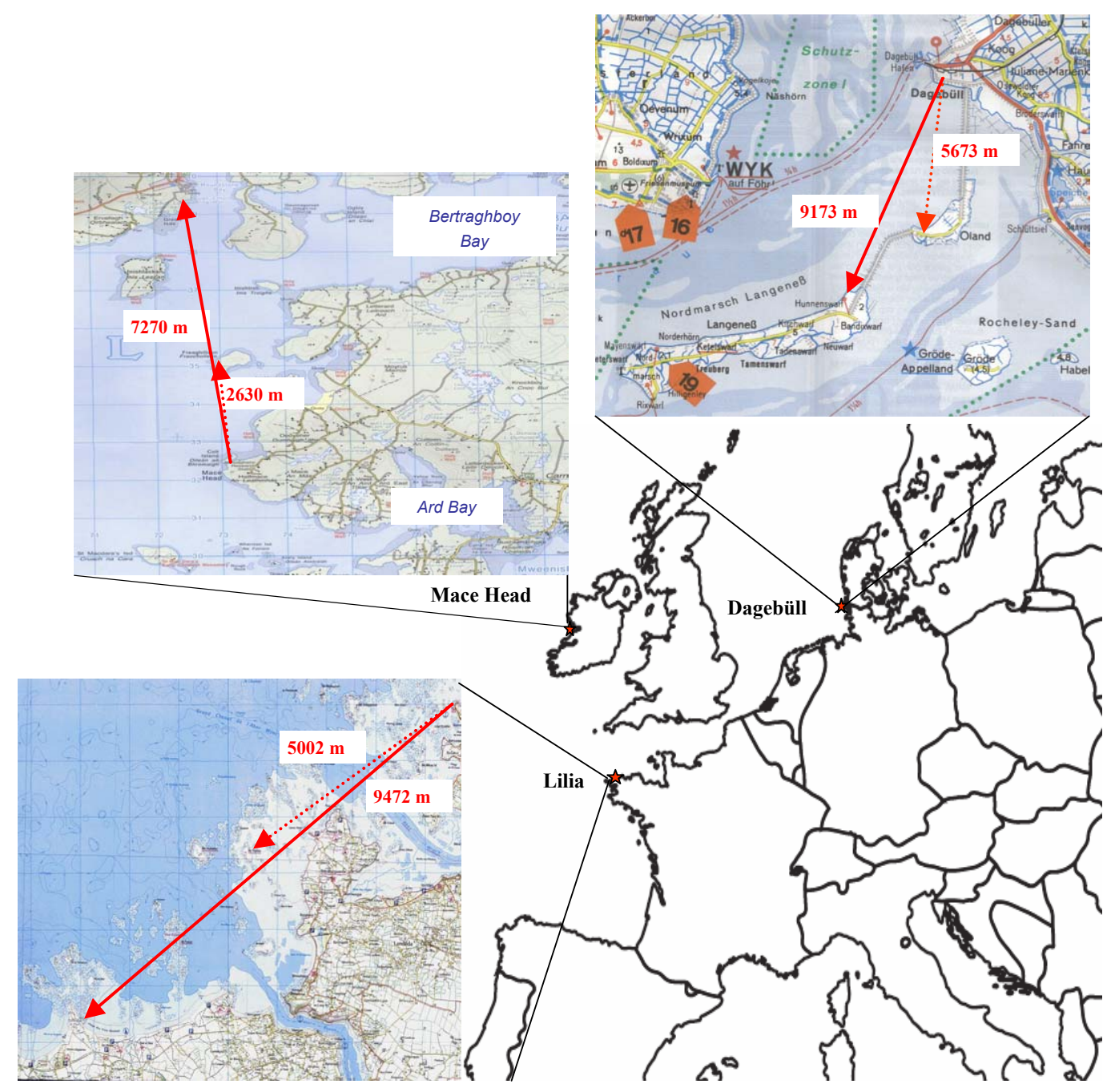

Fig. 2. The three campaign sites Mace Head, Lilia and Dagebüll. The lightpaths are indicated by red arrows. The shorter lightpath (dotted line) was used if the atmospheric conditions didn't allow measurements on the longer one. The shaded areas always indicate the intertidal zones, where the water was removed during low tide. In Dagebüll, as well as, in Lilia the lightpath crossed primarily through the intertidal zone, whereas in Mace Head the lightbeam mainly passed over sea. In the latter location the tidally influenced area with fields of algae is located in easterly direction, e.g. Ard Bay and Bertraghboy Bay.

this paper, seem to indicate that OIO is present in coastal regions, but in average mixing ratios clearly below $10 \mathrm{ppt}$. These mixing ratios are insufficient to explain particle formation processes, according to Burkholder et al. (2004), and they therefore suggested an inhomogeneous source distribution in so-called "hot spots" to explain this apparent discrepancy. However, inhomogeneous distribution of RHS along the lightpath cannot be resolved by longpath DOAS measurements.

The most likely source of reactive iodine is the emission of organohalogens by macroalgae, which would fit well into the picture of inhomogeneous release due to the patchy distribution of algae in coastal regions. Diiodomethane is biogenically emitted by a variety of macroalgae, as reported by
Schall and Heumann (1993); Carpenter et al. (1999). Due to the short photolytic lifetime of $\mathrm{CH}_{2} \mathrm{I}_{2}$, iodine atoms are released within minutes into the atmosphere, where they quickly react with ozone to form IO.

The detection of molecular iodine at Mace Head was recently reported by Saiz-Lopez and Plane (2004), who found highly elevated levels of $I_{2}$ closely correlated to minima in tidal height, again indicating macroalgae to be the source. However, it is unclear if the appearance of $\mathrm{I}_{2}$ is a common phenomenon in the marine boundary layer, since the results have not been confirmed at other coastal sites thus far.

In this study we present field data from three different maritime locations. The first part of this work, the experimental section, addresses the DOAS technique, and the method for 
the determination of the VHOCs with the GC/ECD-ICPMS is briefly explained. In the following section a detailed description of the three different measurement locations (German North Sea Coast, the French Atlantic Coast and Mace Head, Ireland) is given, followed by a description of the DOAS data analysis for the evaluated species $\mathrm{BrO}, \mathrm{IO}$, OIO and $\mathrm{I}_{2}$. In the last section we discuss a comparison of the results with model studies.

\section{Experimental setup}

\subsection{The DOAS system}

The well established method of DOAS (Platt and Perner, 1983; Platt, 1994) identifies and quantifies trace gases by their individual narrow band absorption structures. We used this technique to perform measurements of the RHS IO, $\mathrm{BrO}$, OIO, $\mathrm{I}_{2}$ and further species such as $\mathrm{NO}_{2}, \mathrm{O}_{3}, \mathrm{H}_{2} \mathrm{O}$, $\mathrm{O}_{4}$ and $\mathrm{HCHO}$, with an active longpath DOAS instrument. For the campaigns in 2002 and 2003 the telescope was operated with an artificial light source (active), a high pressure Xe-arc lamp of the type PLI HSA-X5002 (Professional Lamp Inc., USA). The lightbeam was sent through the atmosphere, reflected by an array consisting of 180 quartz prism retro-reflectors at a distance of $9472 \mathrm{~m}$ (Brittany, 2003) and $9173 \mathrm{~m}$ (North Sea, 2002), resulting in a total absorption path length of twice the distance to the reflectors (i.e., $18.9 \mathrm{~km}$ and $18.3 \mathrm{~km}$, respectively). The returning light was analyzed by an Acton 500pro spectrometer $(\mathrm{f}=6.9,600 \mathrm{gr} / \mathrm{mm}$ grating, thermostated to $25 \pm 0.5^{\circ} \mathrm{C}$ ) equipped with a 1024 pixel photodiode array detector (type Hamamatsu S3904-1024), resulting in a spectral resolution of about $0.5 \mathrm{~nm}$ FWHM. Three different wavelength ranges were routinely covered to measure the species of interest: $\mathrm{BrO}$ in $335 \pm 40 \mathrm{~nm}$, IO in $420 \pm 40 \mathrm{~nm}$, OIO as well as $\mathrm{I}_{2}$ in $550 \pm 40 \mathrm{~nm}$. Within these spectral ranges related absorbers such as $\mathrm{NO}_{2}, \mathrm{O}_{3}, \mathrm{HCHO}$, $\mathrm{H}_{2} \mathrm{O}$ and $\mathrm{O}_{4}$ were accounted for as well. The mixing ratios of the respective absorbers were derived by a non-linear least squares fit (Stutz and Platt, 1996), by simultaneously adjusting all relevant absorbers, together with a polynomial and a spectrum for the correction of lamp features to the atmospheric spectrum. An experimental setup with similar characteristics and the same measurements strategy was used at the earlier study at Mace Head (Hebestreit, 2001; Hönninger, 1999). The total light path length in this case was $14.4 \mathrm{~km}$.

\subsection{The GC/ECD-ICPMS}

The measurements of VHOCs for the two recent campaigns were performed by an GC/ECD-ICPMS. Since the detection system is not mobile, air and water samples were taken at the campaign site and analyzed later in the laboratory in Mainz. The air sampling was carried out by adsorption on carbosieve SIII or carboxen in the field, and subsequent thermal desorption of the analytes into a cold trap in the laboratory. Af- ter the cryo-focusing procedure, the VHOCs were separated in a capillary column and determined by an electron capture detector (ECD) coupled on-line to an inductively coupled plasma mass spectrometer (ICPMS). For the analysis of chlorinated and brominated compounds ECD is a highly sensitive method, but for iodinated compounds the ICPMS has the advantage of element specific detection, which is especially important for the identification of unknown and coeluating chromatographic peaks. A schematic overview of the GC/ECD-ICPMS system is given in Fig. 1. For details the reader is referred to Schwarz and Heumann (2002).

\section{Measurement sites}

We present data from three measurement sites. The recent field campaigns at the North Sea in 2002 and in Brittany in 2003 were conducted within the framework of the ReHaTrop project, which is part of the German AFO2000 (Atmospheric Research Program) program. During these two field campaigns VHOCs were measured by the group of Heumann et al., Uni Mainz, and RHS by the group of Platt et al., Univ. Heidelberg. Additionally, data from the 1998 PARFORCE campaign at Mace Head, Ireland was re-analyzed, representing a further coastal environment. An overview on these three measurement sites is given in Fig. 2.

\subsection{Dagebüll, German North Sea Coast}

Between 18 April and 17 May 2002, we conducted an intensive field campaign in Dagebüll $\left(54.73^{\circ} \mathrm{N}, 8.69^{\circ} \mathrm{E}\right)$ at the German North Sea Coast. Tidal effects and the flat coastal area cause the unique character of the nature reserve Wadden Sea. In times of low tide extended areas along the coastline are exposed to the atmosphere. We observed a maximal tidal range of $3.8 \mathrm{~m}$ during the campaign, sufficient to remove the water below the absorption path of the DOAS instrument completely (see Fig. 2). The weather conditions were, in general, stormy and rainy, with just a few sunny periods. These conditions strongly disturbed continuous DOAS measurements. Since spring started late in that year, macroalgae appeared isolated and rarely within the intertidal zone. The atmosphere was moderately polluted, with $0.5-8 \mathrm{ppb} \mathrm{NO}_{2}$ throughout the campaign.

The DOAS instrument was positioned on the top of a dyke at few meters distance to the waterfront in times of high tide. Two different lightpaths were set up and used alternatively, according to the atmospheric visibility. In Fig. 2 both lightpaths are shown for each measurement site with red arrows. The primary lightpath (solid line) crossed the intertidal zone at just 3-7 m height to the small island Langeneß at $9172 \mathrm{~m}$ distance (total length $18.34 \mathrm{~km}$ ).

To determine the impact of the appearance of macroalgae on VHOCs, air samples for the GC/ECD-ICPMS analysis were taken at various locations. We sampled air primarily 
Table 2. Differential absorption cross sections used for the data analysis in this work.

\begin{tabular}{ll}
\hline Species & Reference \\
\hline $\mathrm{HCHO}(298 \mathrm{~K})$ & Meller and Moortgat (2000) \\
$\mathrm{O}_{4}(287 \mathrm{~K})$ & Greenblatt et al. (1990) \\
$\mathrm{O}_{3}(293 \mathrm{k})$ & Voigt et al. (2001) \\
$\mathrm{NO}_{2}(293 \mathrm{~K})$ & Voigt et al. (2002) \\
$\mathrm{H}_{2} \mathrm{O}(298 \mathrm{~K})$ & Coheur et al. (2002) \\
\hline $\mathrm{BrO}(298 \mathrm{~K})$ & Wilmouth et al. (1999) \\
$\mathrm{IO}(295 \mathrm{~K})$ & Hönninger (1999) \\
$\mathrm{OIO}(295 \mathrm{~K})$ & Bloss et al. (2001) \\
$\mathrm{I}_{2}(295 \mathrm{~K})$ & Saiz-Lopez et al. (2004b) \\
\hline
\end{tabular}

at a small water pool at $500 \mathrm{~m}$ distance to the DOAS instrument. This pool was only flooded during very high tide, allowing that some green algae (Ulva Lactuca, Enteromorpha compressa) could grow in this protected area. Air samples were also taken close to the DOAS instrument, within the intertidal zone above sandy ground, but with no macroalgae in the vicinity.

\subsection{Lilia, French Atlantic Coast, Brittany}

The intensive field campaign in 2003 was carried out from 6 May to 13 June in Lilia $\left(48.62^{\circ} \mathrm{N}, 4.55^{\circ} \mathrm{W}\right)$, a small village at the French Atlantic Coast of Brittany, $50 \mathrm{~km}$ north of Brest. In contrast to Dagebüll, the site was characterized by extraordinarily high biological activity. Extended fields of macroalgae were present all along the coast, with a variety of different algae species ranging from green, to brown to red algae e.g. Laminaris, Fucus Vesicolosus, Ascophyllum Nodosum. The measurement site is situated in the north-west of Brittany, directly at the Atlantic Coast. Although clean air was typically transported by westerly flows from the open Atlantic to the site, some pollution by $\mathrm{NO}_{\mathrm{x}}$ species has to be accounted for $\left(\mathrm{NO}_{2}\right.$ of up to $\left.7.5 \mathrm{ppb}\right)$. The campaign took place in late spring close to the summer solstice, with an average of 15.5 sunlight hours, defined as solar zenith angle $\mathrm{SZA}<90^{\circ}$.

As in the previous campaign in 2002 at the North Sea, the DOAS telescope was set up at a few meters distance to the waterfront in times of high tide. The lightpath of $9472 \mathrm{~m}$ length (total absorption length $18.94 \mathrm{~km}$ ), indicated by a solid line in Fig. 2 was primarily used. Only during periods with low atmospheric visibility was the lightpath, indicated in Fig. 2 by a dotted line, used.

The tide in Brittany is quite pronounced, with a maximum in tidal range of $7.5 \mathrm{~m}$ during the campaign. The lightpath crossed the intertidal zone at $10-14 \mathrm{~m}$ height above average sea level. In times of low tide the water was removed to more than $60 \%$ below the lightpath.
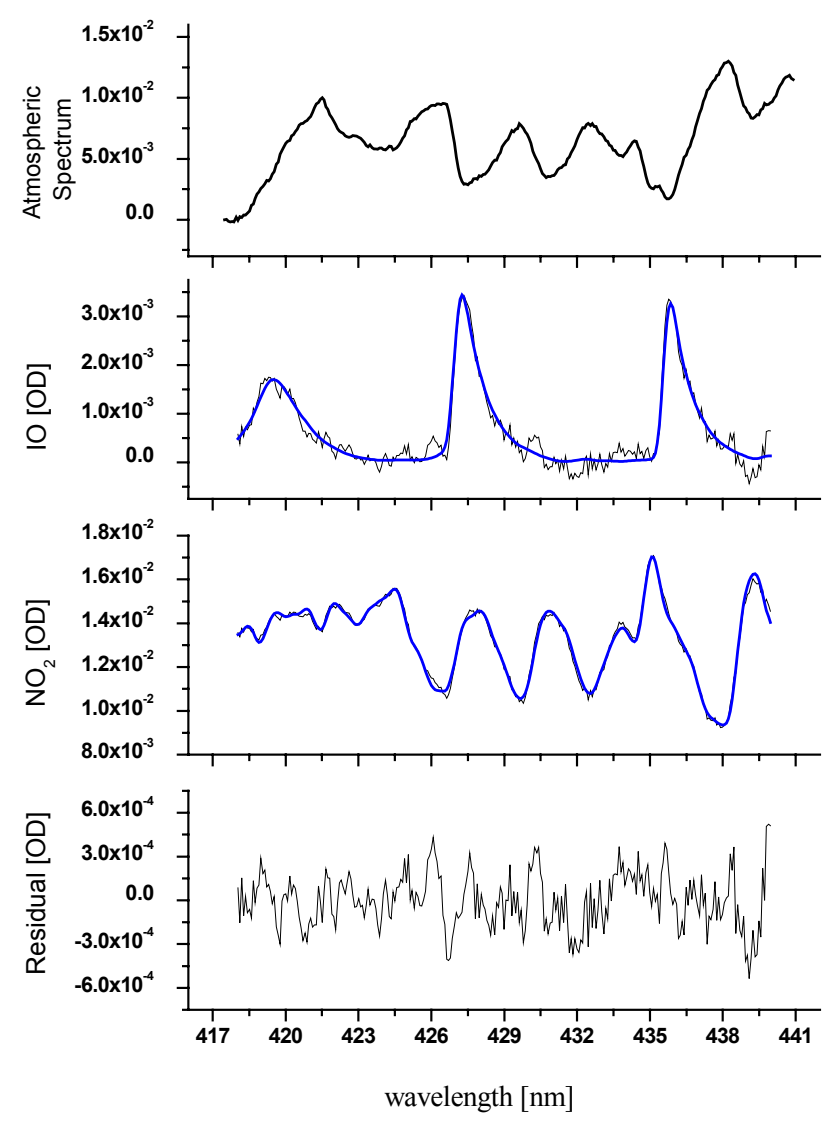

Fig. 3. Sample evaluation of IO. In the upper panel the atmospheric spectrum taken in Brittany on 5 June 2003 at 16:00 GMT is shown, after a highpass filter was applied to remove broad banded spectral features. In the second and third panel the absorption structures assigned to $\mathrm{IO}, \mathrm{NO}_{2}$ are shown. IO is clearly identified, and the mixing ratio corresponds to $2.99 \pm 0.2 \mathrm{ppt}$, assuming a lightpath of nearly $19 \mathrm{~km}$. The residual has a peak to peak noise of $1.06 \times 10^{-3}$ and does not show any regular structures.

During the 2002 North Sea campaign the RHS and VHOC measurements were not co-located to demonstrate the impact of macroalgae on the appearance of VHOCs but during the 2003 Brittany campaign, the VHOCs were measured by always sampling next to the DOAS instrument.

\subsection{Mace Head 1998}

In September/October of 1998 the group of Platt et al. conducted active longpath DOAS measurements during the field campaign in Mace Head, Ireland $\left(53.33^{\circ} \mathrm{N}, 9.90^{\circ} \mathrm{W}\right)$ in the framework of the PARFORCE project. Spectra were taken for the detection of $\mathrm{BrO}, \mathrm{IO}$ and OIO. The results have already been published for $\mathrm{BrO}$ (Sander et al., 2003) as well as for IO (Carpenter et al., 2001).

As $\mathrm{I}_{2}$ was not accounted for in the original analysis, all spectra in the 500-600 $\mathrm{nm}$ range were re-analyzed and the results are discussed in this work. Due to the availability 


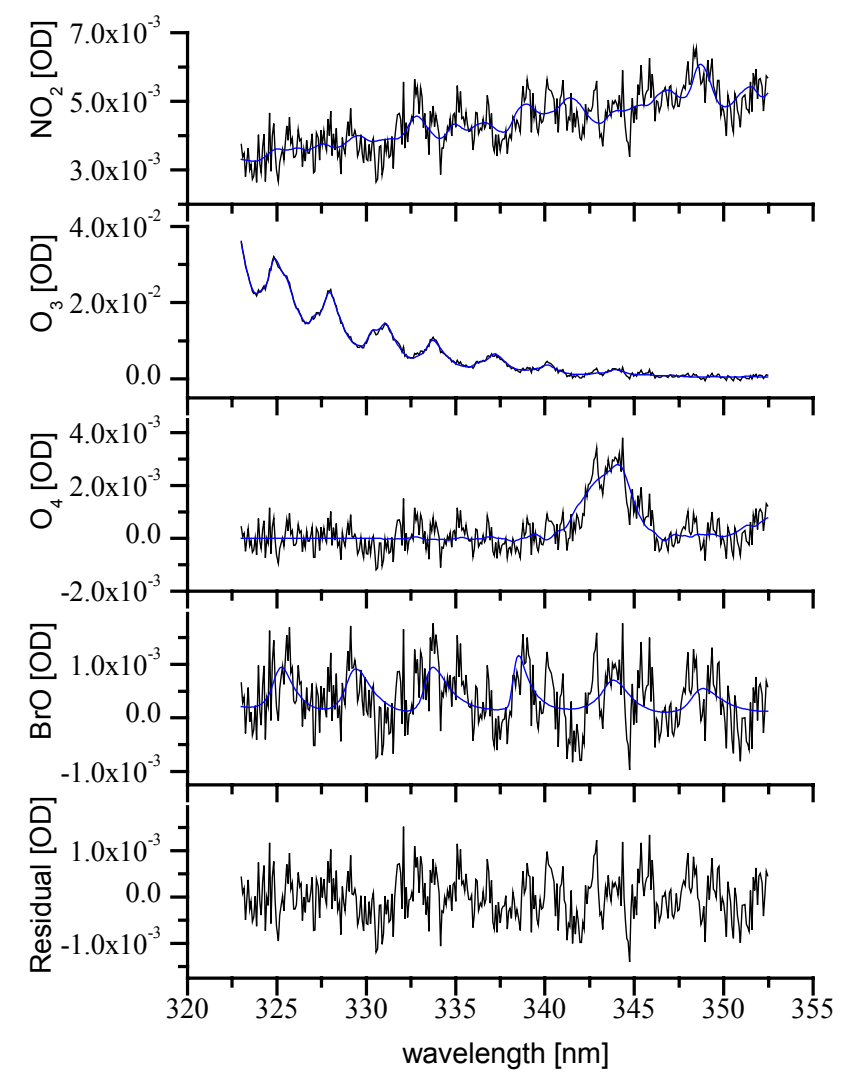

Fig. 4. Sample evaluation of the BrO fit. The absorption structures of $\mathrm{BrO}$ are not clearly identified above the residual, even if there is some evidence for it in this example. The corresponding $\mathrm{BrO}$ mixing ratio for the lightpath of $18.94 \mathrm{~km}$ is $1.45 \pm 0.88 \mathrm{ppt}$.

of better absorption cross section in recent years OIO was also re-analyzed in this wavelength range. Due to a variety of intensive field studies at Mace Head within recent years, a detailed description of the measurement site can be found elsewhere (e.g. Carpenter et al., 2001). The site is, in some ways, very similar to that of Brittany. The coastline is significantly influenced by tidal effects, and the combination of a rocky coast and cold water results in a strong appearance of macroalgae.

The DOAS telescope was installed close to the waterfront. The lightpath was $7.27 \mathrm{~km}$ (total length $14.4 \mathrm{~km}$ ) long, pointing to the opposite side of the bay where a reflector was positioned. The lightbeam mainly crossed ocean water, with only small areas close to the coast that were affected by the tides. However, east of the lightpath, extended fields of macroalgae are exposed to the atmosphere during times of low tide (Ard Bay and Bertraghboy Bay, see Fig. 2).

\section{DOAS data analysis}

The software WinDOAS (Fayt and van Rozendael, 2001) was used to perform a non-linear least squares fit, by simulta-
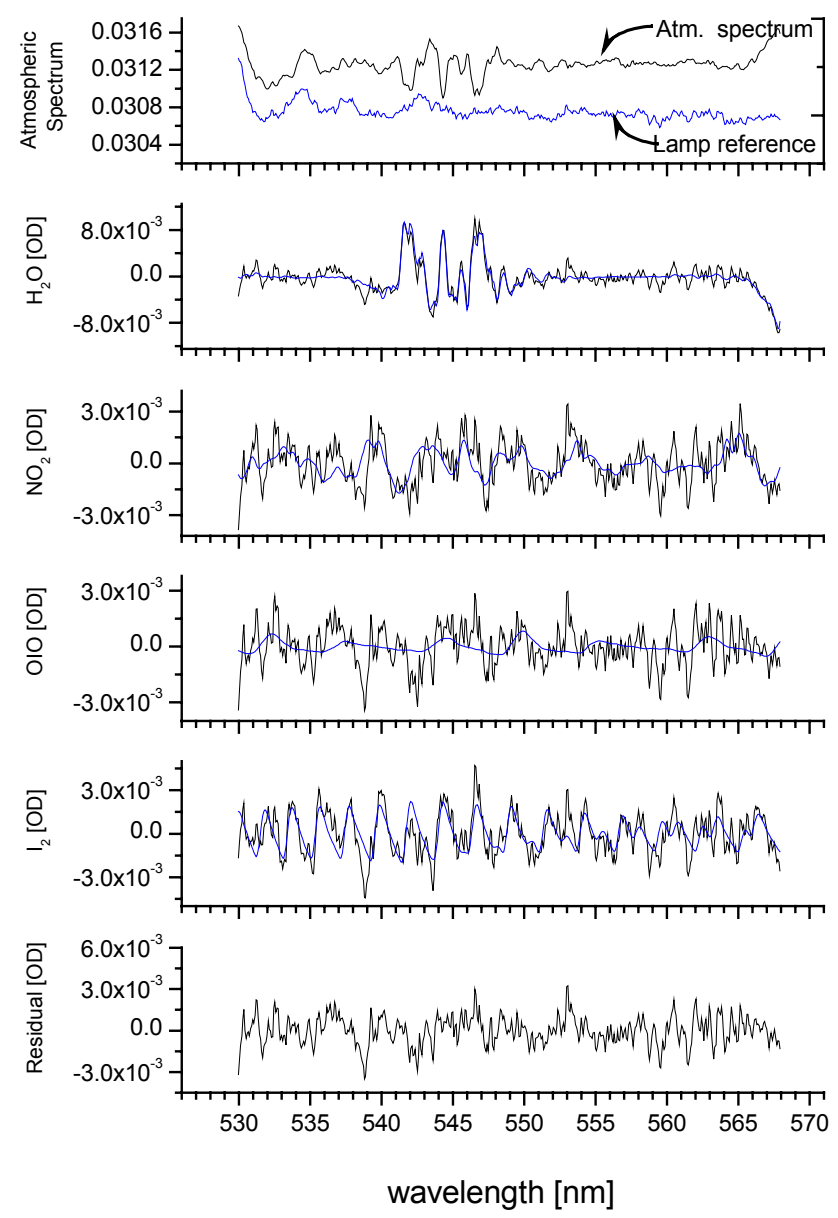

Fig. 5. Example for the spectral identification of $I_{2}$. The spectrum was taken on 5 October 1998 22:07 GMT during the PARFORCE campaign in Mace Head. The corresponding mixing ratio of $I_{2}$ is $61.29 \pm 9.36 \mathrm{ppt}$, and for OIO $5.70 \pm 3.19 \mathrm{ppt}$.

neously adjusting the relevant atmospheric absorbers in the respective wavelength range to the atmospheric spectra. To remove spectral features caused by the DOAS lightsource, a daily recorded lamp reference spectrum, in addition to a polynomial of the 5th order, was included in the fit as well. The detection limit is estimated by multiplying a factor 2 to the statistical error $(1 \sigma)$ resulting from the non linear fit procedure. However, this estimation of the detection limit is only valid for a mostly unstructured residual. For individual cases, if significant residual structures remain, the statistical error has to be multiplied by a factor of up to 3 according to studies by Stutz (1996). Hence, the individual error and therefore the detection limit can be significantly higher than the $2 \sigma$ range for individual cases.

We analyzed IO between 418 and $440 \mathrm{~nm}$, where three of the strongest absorption bands (3-0, 4-0, 5-0) of the electronic transition $\mathrm{A}^{2} \Pi_{3 / 2} \leftarrow X^{2} \Pi_{3 / 2}$ are found. The strong 2-0 band was excluded to avoid conflicts with water absorption and broadened lamp structures in the 
Table 3. Overview of mixing ratios and detection limits at the three described measurement sites. Results of $\mathrm{NO}_{2}, \mathrm{O}_{3}, \mathrm{IO}_{\text {and }} \mathrm{BrO}$ for $\mathrm{Mace}$ Head are adapted from the original analysis by Hebestreit (2001); Hönninger (1999). The average, minimum, and maximum value of the statistical $(2 \sigma)$ detection limit (D.L.) and the mixing ratio (m.r.) for each species is given.

\begin{tabular}{llllll}
\hline & Species & Av.D.L. & Min/Max D.L. & Av.m.r. & Max m.r. $\pm 2 \sigma$ \\
\hline Brittany 2003 & $\mathrm{NO}_{2}$ & $0.23 \mathrm{ppb}$ & $0.09 / 0.73 \mathrm{ppb}$ & $1.02 \mathrm{ppb}$ & $(5.40 \pm 0.26) \mathrm{ppb}$ \\
& $\mathrm{O}_{3}$ & $1.2 \mathrm{ppb}$ & $0.7 / 4.6 \mathrm{ppb}$ & $42.67 \mathrm{ppb}$ & $(88.89 \pm 5.01) \mathrm{ppb}$ \\
& $\mathrm{IO}$ & $0.23 \mathrm{ppt}$ & $0.13 / 0.96 \mathrm{ppt}$ & $0.75 \mathrm{ppt}$ & $(7.7 \pm 0.5) \mathrm{ppt}$ \\
& $\mathrm{BrO}$ & $0.67 \mathrm{ppt}$ & $0.37 / 2.36 \mathrm{ppt}$ & $0.75 \mathrm{ppt}$ & $(3.99 \pm 1.30) \mathrm{ppt}^{\mathrm{b}}$ \\
& $\mathrm{OIO}$ & $1.84 \mathrm{ppt}$ & $0.69 / 5.80 \mathrm{ppt}$ & $-0.24 \mathrm{ppt}$ & $(13.3 \pm 4.96) \mathrm{ppt}^{\mathrm{b}}$ \\
& $\mathrm{I}_{2}$ & $7.58 \mathrm{ppt}$ & $2.84 / 23.95 \mathrm{ppt}$ & $-0.82 \mathrm{ppt}$ & $(23.29 \pm 10.6) \mathrm{ppt}^{\mathrm{b}}$ \\
\hline North Sea 2002 & $\mathrm{NO}_{2}$ & $0.02 \mathrm{ppb}$ & $0.01 / 0.05 \mathrm{ppb}$ & $1.9 \mathrm{ppb}$ & $(8.10 \pm 0.02) \mathrm{ppb}$ \\
& $\mathrm{O}_{3}$ & $2.8 \mathrm{ppb}$ & $1.8 / 23 \mathrm{ppb}$ & $37.25 \mathrm{ppb}$ & $(59.3 \pm 2.6) \mathrm{ppb}$ \\
& $\mathrm{IO}$ & $0.28 \mathrm{ppt}$ & $0.18 / 0.65 \mathrm{ppt}$ & $0.35 \mathrm{ppt}$ & $(1.90 \pm 0.65) \mathrm{ppt}$ \\
& $\mathrm{BrO}$ & $1.47 \mathrm{ppt}$ & $0.6 / 4.08 \mathrm{ppt}$ & $0.2 \mathrm{ppt}$ & $(2.98 \pm 1.36) \mathrm{ppt}$ \\
& $\mathrm{OIO}$ & $2.75 \mathrm{ppt}$ & $1.18 / 12.19 \mathrm{ppt}$ & $4.27 \mathrm{ppt}$ & $(15.26 \pm 6.65) \mathrm{ppt}$ \\
\hline Mace Head 1998 & $\mathrm{NO}_{2}$ & $0.07 \mathrm{ppb}$ & $0.02 / 0.6 \mathrm{ppb}$ & $0.6 \mathrm{ppb}$ & $(6.54 \pm 0.07) \mathrm{ppb}$ \\
& $\mathrm{O}_{3}$ & $4.3 \mathrm{ppb}$ & $1.4 / 15.5 \mathrm{ppb}$ & $32.35 \mathrm{ppb}$ & $(44 \pm 3.9) \mathrm{ppb}$ \\
& $\mathrm{IO}$ & $0.91 \mathrm{ppt}$ & $0.3 / 6 \mathrm{ppt}$ & $0.48 \mathrm{ppt}$ & $(7.2 \pm 0.3) \mathrm{ppt}$ \\
& $\mathrm{BrO}$ & $2.45 \mathrm{ppt}$ & $0.88 / 9.45 \mathrm{ppt}$ & $-1.28 \mathrm{ppt}$ & $(4.1 \pm 4.2) \mathrm{ppt}$ \\
& $\mathrm{OIO}^{\mathrm{a}}{ }^{\mathrm{a}}$ & $3.22 \mathrm{ppt}$ & $1.78 / 5.12 \mathrm{ppt}$ & $0.69 \mathrm{ppt}$ & $(9.19 \pm 1.25) \mathrm{ppt}$ \\
& $\mathrm{I}_{2}{ }^{\mathrm{a}}$ & $9.99 \mathrm{ppt}$ & $7.6 / 27.6 \mathrm{ppt}$ & $6.6 \mathrm{ppt}$ & $(61.29 \pm 12.09) \mathrm{ppt}$ \\
\hline
\end{tabular}

${ }^{\text {a }}$ Re-analysis Mace Head 1998 data

${ }^{b}$ No identification in the spectrum

range of $440-450 \mathrm{~nm}$. The cross section of Hönninger (1999), recorded with a resolution of $0.09 \mathrm{~nm}$, and $\sigma_{\text {diff }}(427.2 \mathrm{~nm})=2.6 \times 10^{-17} \mathrm{~cm}^{2}$ (4-0 transition band) was used. In addition, an absorption cross section of $\mathrm{NO}_{2}$ (see Table 2) was included in the analysis.

Throughout both recent campaigns the detection limit for IO was on average below 0.5 ppt. In Fig. 3 a sample evaluation of 5 June 2003 in the afternoon gives an overview of the spectral identification of IO. The presented spectrum corresponds to a mixing ratio of $2.99 \pm 0.2 \mathrm{ppt}$, which demonstrates the clear identification of three IO absorption bands already at moderate levels.

Due to the long exposure times necessary in the near UV range $(295-375 \mathrm{~nm})$ on absorption paths of nearly $20 \mathrm{~km}$, measurements in this wavelength range were restricted to times with very clear atmospheric conditions. Under clear conditions the acquisition of one spectrum took an average of 5-15 min. The evaluation range was set to $323-352.5 \mathrm{~nm}$, including 6 vibrational transitions of the $\mathrm{A}^{2} \Pi_{3 / 2} \leftarrow X^{2} \Pi_{3 / 2}$ of $\mathrm{BrO}$ transitions to provide an unambiguous spectral identification. Besides the lamp spectrum, a 5th order polynomial and literature absorption cross sections of $\mathrm{O}_{4}, \mathrm{O}_{3}, \mathrm{NO}_{2}$ and $\mathrm{HCHO}$ (see references in Table 2) were applied. A sample evaluation is given in Fig. 4. The optical density of the $\mathrm{BrO}$ absorption is in a similar range as that of the residual. Hence an unambiguous detection of $\mathrm{BrO}$ was not possible.

We evaluated $\mathrm{I}_{2}$ and OIO in the range of $530-568 \mathrm{~nm}$ to provide good spectral identification but to avoid greater con- flicts with highly varying structures caused by the operated light source. We applied the $\mathrm{O}_{4}, \mathrm{NO}_{2}, \mathrm{H}_{2} \mathrm{O}$, OIO and $\mathrm{I}_{2}$ cross sections (references in Table 2) to the fit scenario, besides a 5 th order polynomial according to the extended evaluation range. A sample evaluation of 5 October 1998, 22:07 GMT is shown in Fig. 5. Sixteen absorption bands of $\mathrm{I}_{2}$ could be clearly identified.

Water absorption structures are present over major parts of that wavelength range. Due to the incompleteness of available water vapor line databases, the removal of water vapor absorptions in the spectra is partly insufficient and causes high residual structures. In addition, varying structures of the light source have to be accounted for. These structures vary strongly in time, and the remaining structures in the residual are not stable or interpretable in a simple way as an instrumental effect.

\section{Results and discussion}

In the following section, the results for determined VHOCs, $\mathrm{IO}, \mathrm{BrO}, \mathrm{OIO}$, and $\mathrm{I}_{2}$ are presented and discussed for the campaigns described above. Additionally, we compare the results of the 2003 Brittany campaign to model calculations with the marine boundary layer model MISTRA in order to check for consistency of our observations with the present understanding of atmospheric chemistry. A complete overview on the results and the respective detection limits of 
Table 4. The concentration range of all continuously detected iodinated and brominated hydrocarbons is given. If comparable data was available, the range of published data is given. "nd" means below the detection limit.

\begin{tabular}{lccccc}
\hline $\begin{array}{l}\text { Species } \\
\text { Air samples } \\
\text { [pptv] }\end{array}$ & $\begin{array}{c}\text { Lilia } \\
\text { Brittany } \\
\text { this work } \\
2003\end{array}$ & $\begin{array}{c}\text { Brest } \\
\text { Brittany } \\
\text { Pruvost (2001) } \\
2000\end{array}$ & $\begin{array}{c}\text { Mace Head } \\
\text { Ireland } \\
\text { Carpenter et al. (1999) } \\
1999\end{array}$ & $\begin{array}{c}\text { Dagebüll } \\
\text { North Sea } \\
\text { this work } \\
2002\end{array}$ & $\begin{array}{c}\text { Gran Can. } \\
\text { Can. Islands } \\
\text { Ekdahl et al. (1998) } \\
1998\end{array}$ \\
\hline $\mathrm{CH}_{3} \mathrm{I}$ & $7.6-1830$ & $5.7-386$ & $0.1-1.5$ & $4.7-23.5$ & $24-84$ \\
$\mathrm{C}_{2} \mathrm{H}_{5} \mathrm{I}$ & $2.22-96.9$ & & $0.02-1.2$ & $0.3-0.7$ & \\
$2-\mathrm{C}_{3} \mathrm{H}_{7} \mathrm{I}$ & $0.2-9.1$ & & & $0.1-0.3$ & \\
$1-\mathrm{C}_{3} \mathrm{H}_{7} \mathrm{I}$ & $0.35-34.8$ & & & $0.01-1$ & \\
$\mathrm{CH}_{2} \mathrm{ClI}$ & $0.35-12.4$ & $0.9-2.7$ & nd-0.02 & $0.1-3$ & nd-19 \\
$\mathrm{CH}_{2} \mathrm{BrI}$ & $0.55-9.9$ & & & $0.04-0.2$ & \\
$1-\mathrm{C}_{4} \mathrm{H}_{9} \mathrm{I}$ & $0.84-321$ & & & $0.2-1.1$ & $10-89$ \\
$2-\mathrm{C}_{4} \mathrm{H}_{9} \mathrm{I}$ & $0.12-12.3$ & & $0.02-0.3$ & $0.02-0.1$ & \\
$\mathrm{i}-\mathrm{C}_{4} \mathrm{H}_{9} \mathrm{I}$ & $0.2-14.4$ & & & $0.04-0.2$ & \\
$\mathrm{CH}_{2} \mathrm{I}_{2}$ & $0.11-19.8$ & $0-57$ & $0.02-0.4$ & $0.3-3.1$ & \\
\hline $\mathrm{CH}_{3} \mathrm{Br}$ & $12.2-875$ & & $9-26$ & $3.1-23.2$ & \\
$\mathrm{C}_{2} \mathrm{H}_{5} \mathrm{Br}$ & $11.3-865$ & & $0.1-0.5$ & $0.3-1.8$ & \\
$\mathrm{CH}_{2} \mathrm{Br} 2$ & $2.36-262$ & $1-12.1$ & & $0.4-2$ & $37-340$ \\
$\mathrm{CHBrCl}_{2}$ & $12.5-246$ & $0.3-1.8$ & & $0.1-1.2$ & $6-290$ \\
$\mathrm{CHBr}_{2} \mathrm{Cl}$ & $3.47-128.2$ & $0.3-1.9$ & $0.3-1.8$ & $0.2-1.2$ & $19-130$ \\
$\mathrm{CHBr}_{3}$ & $10.5-393$ & $3.8-58$ & $2-16$ & $1.1-11.2$ & $500-2500$ \\
\hline
\end{tabular}

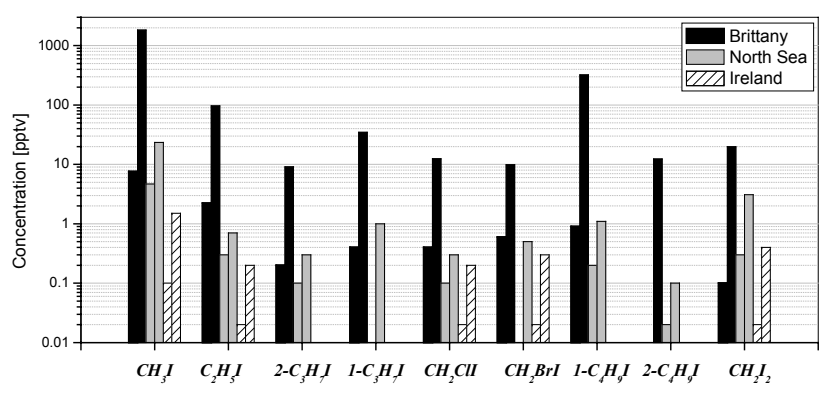

Fig. 6. Diagram for different iodinated VHOCs at three different coastal sites. For each location the average and maximum detected mixing ratios is indicated. The bars are missing if no data was available or the mixing ratios were to close to zero. Note the logarithmic scale.

the RHS measurements by longpath DOAS is given in Table 3 , and the respective overview of results of the VHOC measurements in air is shown in Table 4.

\subsection{VHOC in-situ measurements}

Ten iodinated and six brominated volatile hydrocarbons in air were identified at both 2002 North Sea and 2003 Brittany campaign sites. The detected mixing ratios ranges for these species are summarized in Table 4. Data from two other coastal regions (i.e. Brest and Gran Canaria) are added whenever reported measurements were available.
The detected species show significantly elevated levels for the measurement site in Lilia (Brittany) which can be seen in Fig. 6, where the average and maximum detected concentration of iodocarbons at the three measurement sites (North Sea, Brittany and Mace Head) are compared.

In several cases (e.g. $\mathrm{CH}_{3} \mathrm{I}, \mathrm{CH}_{3} \mathrm{Br}$ ), the observed levels exceed that of other coastal regions by up to two orders of magnitude, demonstrating the outstanding biological activity of Brittany. The mixing ratio ranges, especially for the brominated species measured during the Dagebüll campaign, are in good agreement with observations at Mace Head, Ireland (see Table 4).

In incubation experiments performed with several macroalgae during the 2002 North Sea campaign, characteristic production patterns for different algae species were found, which are in agreement with former investigations of polar macroalgae (Schall et al., 1994). However, the general production pattern seems to be unique for different algae species. It should be noted that the absolute production rate differed significantly between single incubation experiments, which may be explained by the impact of stress factors, as well as the biological state and age of the plant. In Fig. 7 the emission fingerprints of three different algae species, populating the German North Sea coast are shown.

These emission fingerprints show good agreement with VHOC measurements taken at different locations which were dominated by the respective type of macroalgae, as can be seen in Fig. 8. 


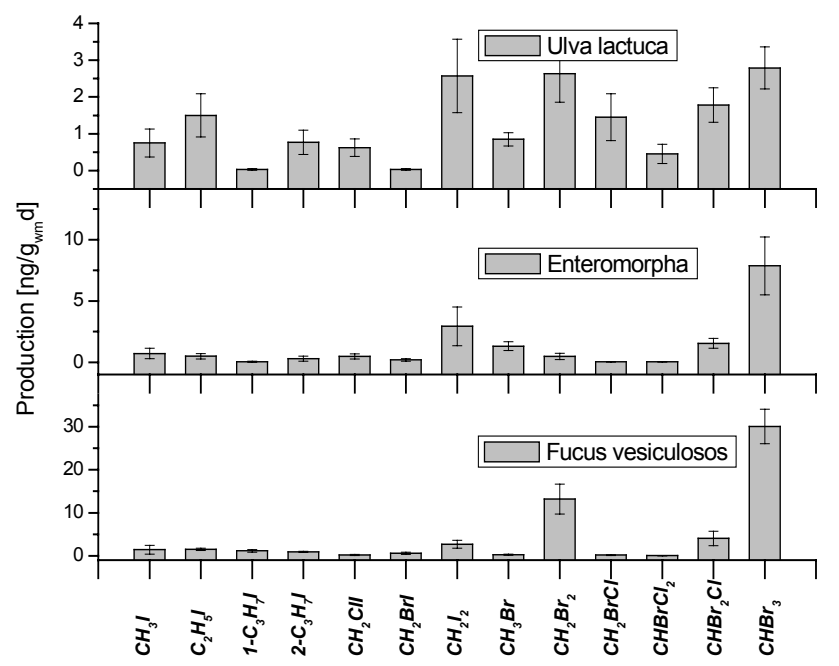

Fig. 7. Fingerprints of VHOC emissions of three different algae found at the German North Sea Coast. The data is averaged over several incubation experiments during 2001 and 2002 at the German North Sea Coast.

The sampling location without macroalgae was situated close to the DOAS telescope in the nearby intertidal zone, while the location with green algae was an enclosed water pool at a distance of $500 \mathrm{~m}$. Air samples were also taken $3.5 \mathrm{~km}$ away from the DOAS instrument at Schüttsiel, where a small population of the brown algae Fucus Vesiculosus inhabited parts of the coast line. The comparison to the fingerprints resulting from incubation experiments shows the clear influence of macroalgae on the detected levels of VHOCs, and indicates that the production pattern is characteristic for the individual algae species in their respective natural habitat.

During the North Sea campaign a phytoplankton bloom was detected, and the emission rates of the VHOCs $\mathrm{CH}_{3} \mathrm{I}$ and $\mathrm{C}_{2} \mathrm{H}_{5} \mathrm{I}$ increased in a correlated manner. In Fig. $8, \mathrm{CH}_{3} \mathrm{I}$ and $\mathrm{CH}_{3} \mathrm{Br}$ show comparable concentrations at all of the locations, which can be easily understood by the long photolytic lifetimes of both species. The existence of open ocean sources and the impact of microplankton on appearance of VHOCs were already indicated by estimations of Carpenter (2003), who found that seaweed production calculated from measured emission rates, in conjunction with biomass estimates, could not support the levels of $\mathrm{CH}_{3} \mathrm{I}$ and $\mathrm{CH}_{2} \mathrm{ICl}$ measured in surface coastal waters off the coast of Mace Head. That lead to her suggestion of additional marine sources for these compounds. The influence of tidal effects on the appearance of VHOCs was analyzed in detail during the Brittany campaign in 2003. For most VHOCs, a strong increase during low tide periods was observed. This is demonstrated in Fig. 9 for the short-lived iodocarbons $\mathrm{CH}_{2} \mathrm{I}_{2}$ and $\mathrm{CH}_{2} \mathrm{IBr}$. As could be expected from the short photolytic lifetime, the concentrations of these species are significantly lower during the day. A clear anticorrelation to tidal height could be observed for the nighttime data. However, as shown in Fig. 9,

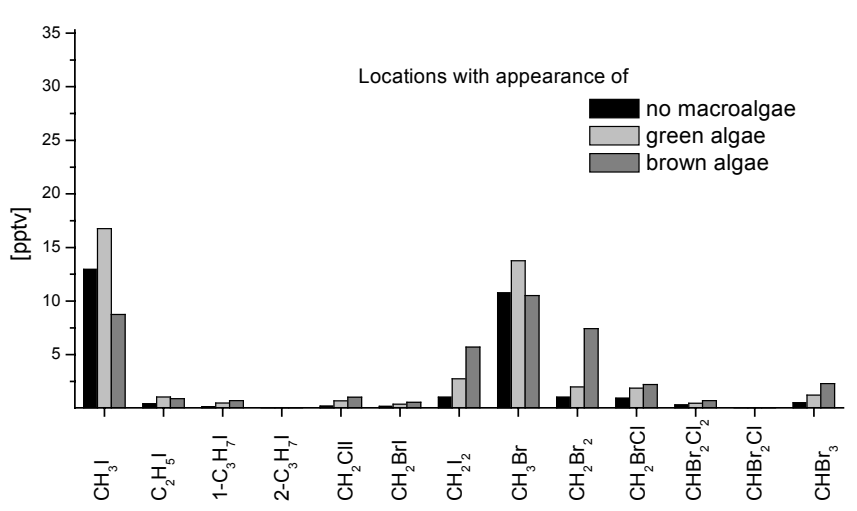

Fig. 8. Average concentrations of VHOCs in air samples taken at different locations during the North Sea campaign (Dagebüll) in Spring 2002. The shading of the bars indicates the type of algae found at the sampling site. Except for $\mathrm{CH}_{3} \mathrm{I}$ and $\mathrm{CH}_{3} \mathrm{Br}$ the concentrations are significantly lower if no macroalgae are present in the vicinity at the sampling site.

two measurements of $\mathrm{CH}_{2} \mathrm{I}_{2}$ exceed 10 pptv during high tide, in both cases very shortly after sunset, which we cannot explain conclusively.

\subsection{Results of IO analysis}

During the North Sea campaign in Spring 2002, the IO radical was the only identified halogen oxide. We detected a maximum of $1.9 \pm 0.65 \mathrm{ppt}$. Due to the problematic weather conditions we did not record a continuous time series, thus we did not observe daily cycles, as in Brittany or in Mace Head. Correlations of halogen activation to the source species $\left(\mathrm{CH}_{2} \mathrm{I}_{2}\right)$ could not be observed either. During the 2003 Brittany campaign we detected a maximum mixing ratio of IO at about $7.7 \pm 0.5 \mathrm{ppt}$, which is comparable to maxima we found in Mace Head during the 1998 PARFORCE campaign. In Fig. 10 the time series of all relevant species taken during the 2003 Brittany campaign is given. We observed a strong diurnal cycle for IO on every day, closely correlated to low tide, as can be seen in Fig. 11. Small amounts of the IO radical of up to $1.0 \mathrm{ppt}$ were found during daytime high tides, but since the water level in Brittany is very variable and the coastline very craggy, a complete coverage of the algae was never assured. Hence, a possible open ocean source for reactive iodine cannot necessarily be inferred from our results. However, the data set demonstrates clearly that macroalgae, exposed to air are the main contributors for reactive iodine in the lower atmosphere. The time series recorded between 24-28 May is shown in Fig. 12 (upper panel). High tide occurred around noon. The IO peaked two times a day and showed a minimum at midday. The peaks coincided with low tide, when the area of exposed algae was enhanced and the production of most VHOCs was significantly elevated (compare Fig. 9). From 2-5 June, low tide occurred 

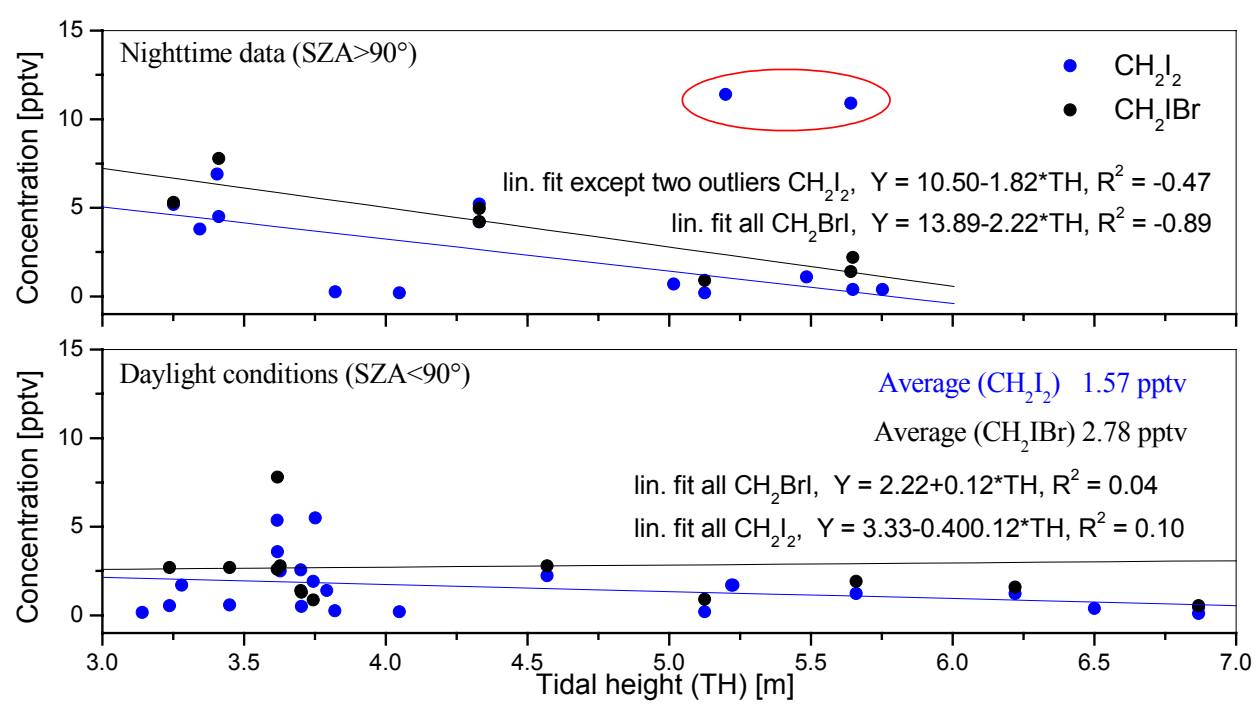

Fig. 9. Concentration of the short lived iodocarbons $\mathrm{CH}_{2} \mathrm{IBr}$ and $\mathrm{CH}_{2} \mathrm{I}_{2}$ in the absence (upper panel) and in the presence (lower panel) of sunlight during 2003 Brittany campaign. At night the observed concentration of the iodocarbons significantly decreases with increasing water level. The error bars are estimated to be in the order of 10\%, see Schwarz and Heumann (2002). The outliers in the upper panel exceed 10 pptv during high tide, both cases shortly after sunset, may indicate a late accumulation of the short lived $\mathrm{CH}_{2} \mathrm{I}_{2}$.

at midday, and we observed a nicely pronounced IO daytime cycle on four consecutive days, with peak IO mixing ratios apparently more elevated than during the May period (see different y-axis scale in Fig. 12) This finding is in qualitative good agreement with respective model calculations (see Sect. 5.5.2).

\subsection{Results of $\mathrm{BrO}$ analysis}

The unambiguous identification of $\mathrm{BrO}$ absorption structures in the spectra was not possible in any of the three described campaigns. The average statistical detection limit for $\mathrm{BrO}$ from the North Sea data set was $1.47 \mathrm{ppt}$, slightly above the estimated limit resulting from the 2003 Brittany campaign with 1.35 ppt. For the Mace Head campaign in 1998, Hönninger (1999) gives a mean detection limit of $2.45 \mathrm{ppt}$. Detection limits and maximal values for $\mathrm{BrO}$ are listed in $\mathrm{Ta}-$ ble 3. These results confirm upper limits for $\mathrm{BrO}$ in the $\mathrm{MBL}$ of 1.5-2 ppt, as previously reported from several coastal sites (Sander et al., 2003, and references herein). BrO mixing ratios below the detection limit are also predicted by the respective model studies for Brittany (see Sect. 5.5.2). Our measurements in Brittany can also be understood as an upper limit for $\mathrm{BrO}$ from organic sources, since we measured $\mathrm{CH}_{2} \mathrm{IBr}$ as a possible source for reactive bromine in exceptionally high mixing ratios (up to $10 \mathrm{ppt}$ ), which have thus far not been reported. Brominated hydrocarbons have lifetimes on the order of days and weeks, with the exception of $\mathrm{CH}_{2} \mathrm{IBr}$, which has a photolytic lifetime of $\sim 1 \mathrm{~h}$ (Mössinger et al., 1998). A statistical analysis of all BrO data taken during the Brittany campaign gives no indication that organic species are precursors for $\mathrm{BrO}$, since there is no dependency of the $\mathrm{BrO}$ signal on tidal height or the appearance of brominated hydrocarbons. However, due to the insufficient sensitivity of the instrument, no further conclusions can be drawn. A modelling sensitivity study suggests that $\mathrm{BrO}$ mixing ratios are affected by such high $\mathrm{CH}_{2} \mathrm{IBr}$ mixing ratios, although well below the detection limit of the DOAS method (see Sect. 5.5.2).

\subsection{Results of $\mathrm{OIO}$ and $\mathrm{I}_{2}$ analysis}

We were not able to identify the absorption structures of OIO or $\mathrm{I}_{2}$ unambiguously in the spectra during the campaigns at the North Sea and Brittany. Although the mixing ratio exceeds several times the statistical $2 \sigma$ detection limit (maximum mixing ratios of $13.3 \mathrm{ppt}$ in Brittany, $15.3 \mathrm{ppt}$ at the North Sea, see Table 3), the optical density of the respective absorption structure is in the same order as the residual, so that no definite statement is possible. The analysis in the $500-600 \mathrm{~nm}$ region has some principal problems causing these high residual structures that resulted in high errors for individual cases, that well exceed the respective statistical $2 \sigma$ detection limit. The observations of OIO above the detection limit during two evenings of the experiment in Mace Head 1998 confirms the report of OIO at Mace Head by Saiz-Lopez and Plane (2004), but it should be noted that the unambiguous identification of the OIO absorptions in the spectra has as well difficulties. The time series in Fig. 15 is only shown for times with stable lamp reference structures. In the remaining time (16-29 September) the interference of the temporarily varying lamp structures with the OIO absorptions were too strong to allow the identification of OIO. The appearance and the magnitude of OIO in the MBL is of great 


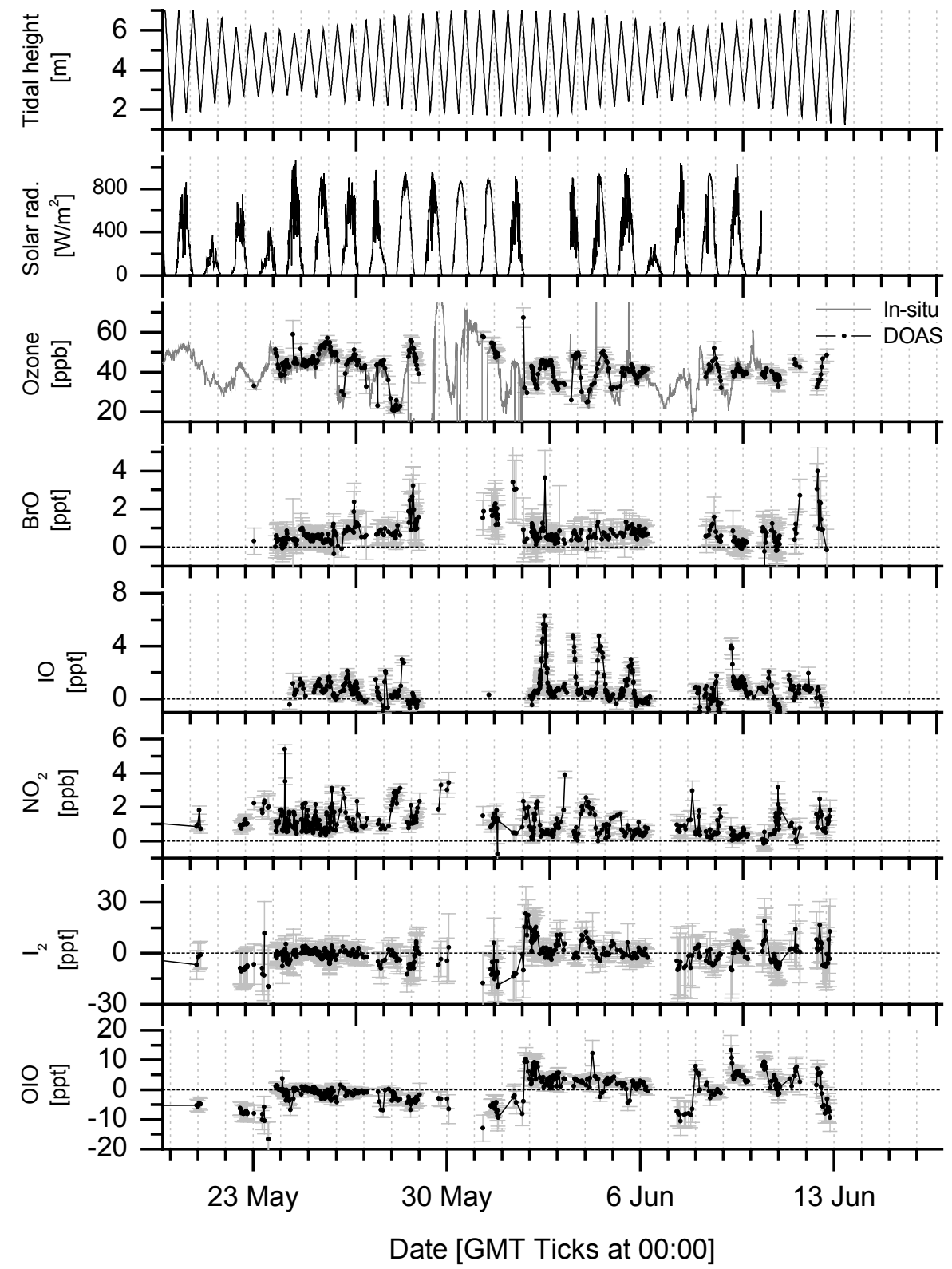

Fig. 10. The time series for the RHS compounds, $\mathrm{NO}_{2}$ and $\mathrm{O}_{3}$ for the campaign in Lilia, Brittany during May and June, 2003. Neither $\mathrm{I}_{2}$ and $\mathrm{OIO}$ nor $\mathrm{BrO}$ could be identified unequivocally above their respective detection limits.

interest due to the possible impact on new particle formation processes. In this respect we have to consider that our DOAS measurements along the absorption-paths of $\sim 20 \mathrm{~km}$ were not suitable to detect inhomogeneous sources for OIO as proposed by Burkholder et al. (2004), due to averaging over extended airmasses in time and space. In contrast to the results in Brittany, we could identify $I_{2}$ successfully in the Mace Head data set of 1998, with peak mixing ratios of more than $60 \mathrm{ppt}$. The complete $\mathrm{I}_{2}$ time series with corresponding tidal height is given in Fig. 13. The highest mixing ratio of $\mathrm{I}_{2}$ was detected at the end of the campaign on three consecutive nights. Within a short time frame the $\mathrm{I}_{2}$ increased rapidly from below the detection limit to peak values of more than $60 \mathrm{ppt}$ (see Fig. 14). The abrupt rise of the $\mathrm{I}_{2}$ mixing ratio is closely correlated to the minima in tidal height. With rising water level, $\mathrm{I}_{2}$ disappeared as fast as it appeared. $I_{2}$ was observed for the first time in Mace Head during the 2002 NAMBLEX campaign by Saiz-Lopez and Plane (2004). They reported $\mathrm{I}_{2}$ mixing ratios of up to $93 \mathrm{ppt}$ at night (and $25 \mathrm{ppt}$ during daytime) measured by active longpath DOAS technique. The peak mixing ratios appeared closely correlated to low tide, indicating macroalgae as the 


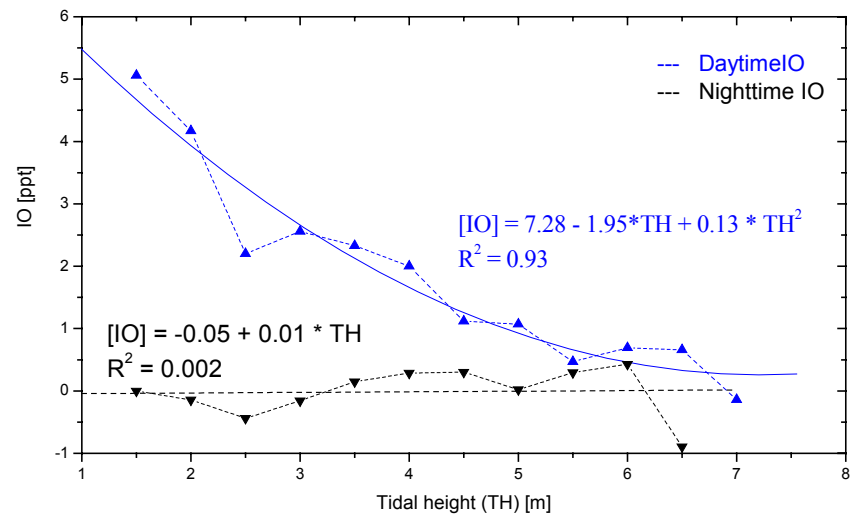

Fig. 11. Correlation of IO mixing ratio with tidal height, separated for day and nighttime data, taken in Brittany 2003. For better illustration the IO mixing ratios are averaged over units of $0.5 \mathrm{~m}$ tidal height.

primary source. Although large numbers of macroalgae were present at the coast of Brittany, we could not identify $\mathrm{I}_{2}$ above the statistical detection limit. However, we could not exclude $\mathrm{I}_{2}$ to be present below the detection limit, which would still have a considerable impact for atmospheric chemistry (see Sect. 5.5.2).

Our re-analysis of the 1998 Mace Head campaign shows up to 60 ppt $\mathrm{I}_{2}$ confirming previous observations of $\mathrm{I}_{2}$ in Mace Head. This rises the question about the presence of $I_{2}$ at other coastal regions. It should be noted, that these differences cannot be explained by the analysis method, which was identical for the data sets of all campaign sites. Mace Head and the coast of Brittany are populated with similar and identical macroalgae species, such as Laminaria, which is known for its high content of iodine. Laminaria is commonly found in the lower intertidal and sublittoral fringe. Consequently, Laminaria is not exposed to ambient air frequently, except during spring-tide, when the water reaches exceptionally low levels. Our observations of $\mathrm{I}_{2}$ on 5, 6, and 7 October in Mace Head show a fast nocturnal increase of $I_{2}$, with mixing ratios of more than $50 \mathrm{ppt}$, which is well correlated with springtide. During these periods the sea level is about $0.6 \mathrm{~m}$ lower than at normal low tide periods. Figure 14 shows that the $I_{2}$ mixing ratio exceeds the $30 \mathrm{ppt}$ mark when the water level decreases below the normal low tide minimum of $0.64 \mathrm{~m}$. High $I_{2}$ levels were only observed at the end of the Mace Head campaign, when the wind came from easterly directions (see Fig. 15), where extended algae fields are found, as described in the Sect. 3.3. While we observed elevated levels of IO during the day and OIO during some evenings, $\mathrm{I}_{2}$ was not as clearly observed during spring-tide in early September. We attribute this finding to the different wind directions during this period. During the normal low tide period in the middle of the campaign, we also did not find elevated levels of $\mathrm{I}_{2}$, despite the easterly wind direction. From the correla- tion of $\mathrm{I}_{2}$ with spring-tide during periods with easterly winds we conclude that macroalgae inhabiting the lowest part of the intertidal zone, such as Laminaria, are the most likely source for the observed $\mathrm{I}_{2}$ at Mace Head. The high $\mathrm{I}_{2}$ mixing ratios indicate that these algae produce $\mathrm{I}_{2}$ at extremely high rates during times when they are exposed to ambient air, i.e., during spring-tide.

In Brittany we found a great variety of different algae, which were regularly exposed to the atmosphere over extended areas during tidal minima, but no evidence for elevated $\mathrm{I}_{2}$ emissions. Since the laminaria species preferably inhabit areas unaffected by the normal tide, the plants are located far off the coast due to the high tidal range of up to $14 \mathrm{~m}$. The laminaria species present in Brittany were therefore maybe too far from the DOAS instrument to yield detectable $I_{2}$ levels. The absence of $I_{2}$ in Brittany therefore does not contradict our theory of the $\mathrm{I}_{2}$ sources in coastal areas.

Although our results suggest that only some exclusive algae species are able to emit $I_{2}$ into the gas phase, we can not exclude the potential impact of the biological state and age of the plant on the $\mathrm{I}_{2}$ emissions. Both campaigns in 1998 and 2002 in Mace Head where $I_{2}$ was detected were conducted in late summer and autumn, whereas the campaign in Brittany took place in spring. This may imply differences in air and sea temperatures that could also affect plant stress.

\subsection{Modelling}

In order to compare some of the conclusions gained from the measurements with the present understanding of halogen chemistry, we present results of model calculations with the marine boundary model MISTRA.

\subsubsection{Model description}

The 1-D column model MISTRA includes detailed particle microphysics, as well as chemical reactions in the gas and aerosol phase, focusing on reaction cycles of halogen compounds. MISTRA has already been used to address different aspects of halogen chemistry in the marine boundary layer (von Glasow and Sander, 2001; von Glasow et al., 2002b,a). The model configuration employed here mostly resembles the base run described in detail in von Glasow et al. (2002b), representing conditions for a clean marine mid-latitude summer atmosphere. The chemical reaction scheme (in particular with regards to iodine chemistry) has been updated according to Atkinson et al. (2004). For the self-reaction of IO, the mean branching ratios of Bloss et al. (2001) are used. The self-reaction of OIO (which is assumed to be photolytically stable), as well as reactions of $\mathrm{OIO}$ with $\mathrm{OH}$ and $\mathrm{NO}$, are included in analogy to von Glasow et al. (2002b). Possible homogeneous nucleation of OIO is neglected. The meteorological conditions assumed in our study represent a cloud-free day in Brittany in the beginning of June (latitude $48.62^{\circ} \mathrm{N}$, 

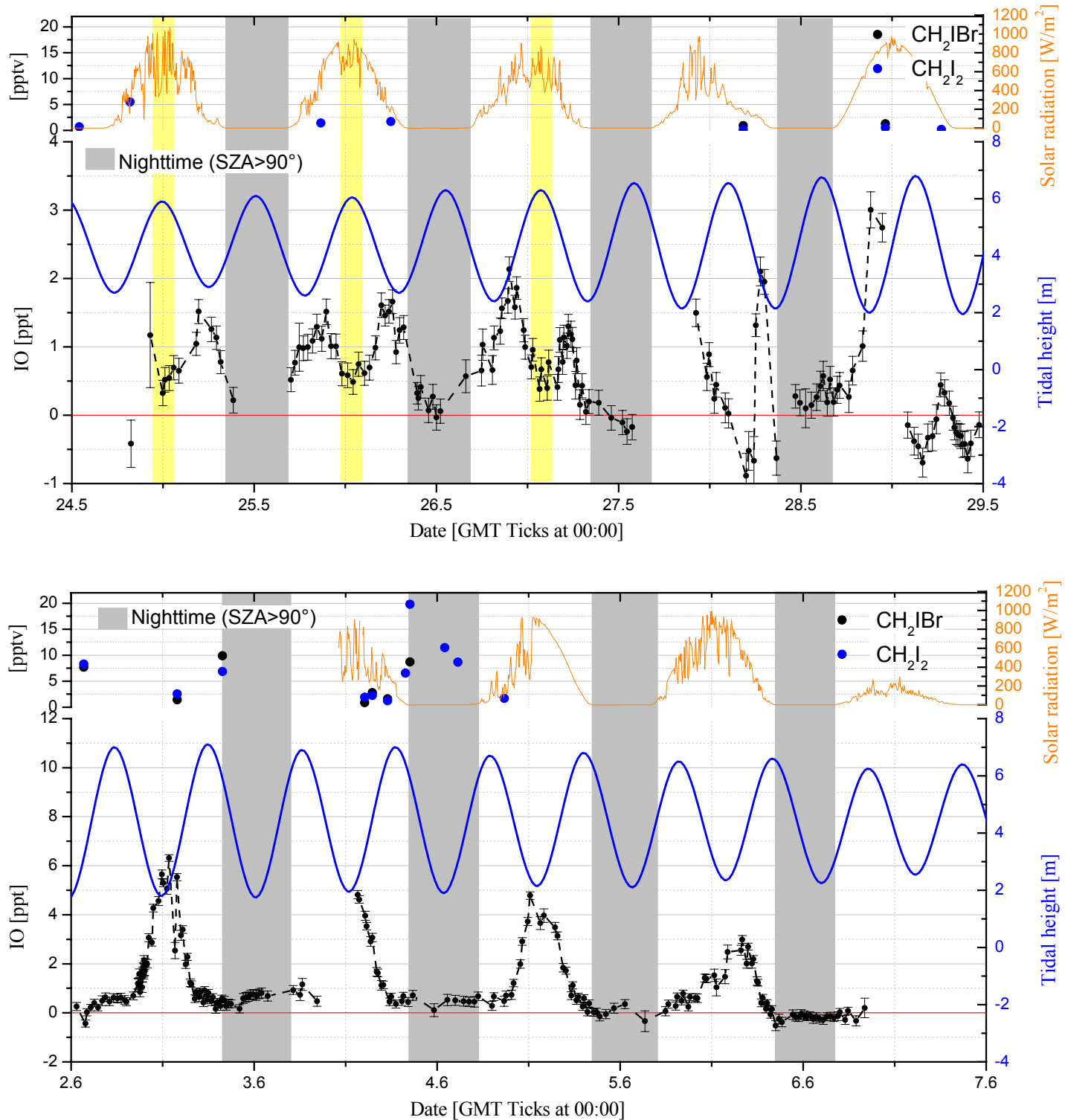

Fig. 12. Sequences of the recorded time series for IO of the 2003 Brittany campaign. The blue line indicates the tidal height and grey shaded areas indicate dark conditions $\left(\mathrm{SZA} \geq 90^{\circ}\right)$.

Upper panel: High tide occurred at midday, and the IO peaks are observed in the morning and in the evening, and are well correlated to the minima of the water level.

Lower panel: The minimum in tidal height coincides with maxima of solar flux and we observed the strongest peak of the IO mixing ratio on four consecutive days.

sun declination $22^{\circ}$ ). Furthermore, higher $\mathrm{NO}_{2}$ mixing ratios compared to von Glasow et al. (2002b) of about $1 \mathrm{ppb}$ (as measured in Brittany) were used for model initialization. Vertical turbulent mixing is accounted for in the model.

After a "spin-up" period of 2 days of meteorology and chemistry assuming open-ocean conditions, different scenarios are performed, each for 6 model hours. During model hours 2 to 4 , constant mixing ratios of organoiodines are prescribed in the lowest $15 \mathrm{~m}$ of the model, based on values measured in Brittany as a simple representation of en- hanced mixing ratios of alkyl iodines during low tide. We simulated four scenarios prescribing different mixing ratios of organoiodines inferred from the measurements in Brittany: Scenarios 1, 2, and 3 use daytime mean, midday maximum, and daytime maximum values of alkyl iodine, respectively, while scenario 0 denotes a model run without any emissions of organoiodines. The exact values are provided in Table 5. Each scenario was performed for morning (04:00-10:00 a.m. local time, assuming low tide from 05:0008:00 a.m.) and midday conditions (10:00 a.m.-04:00 p.m., 


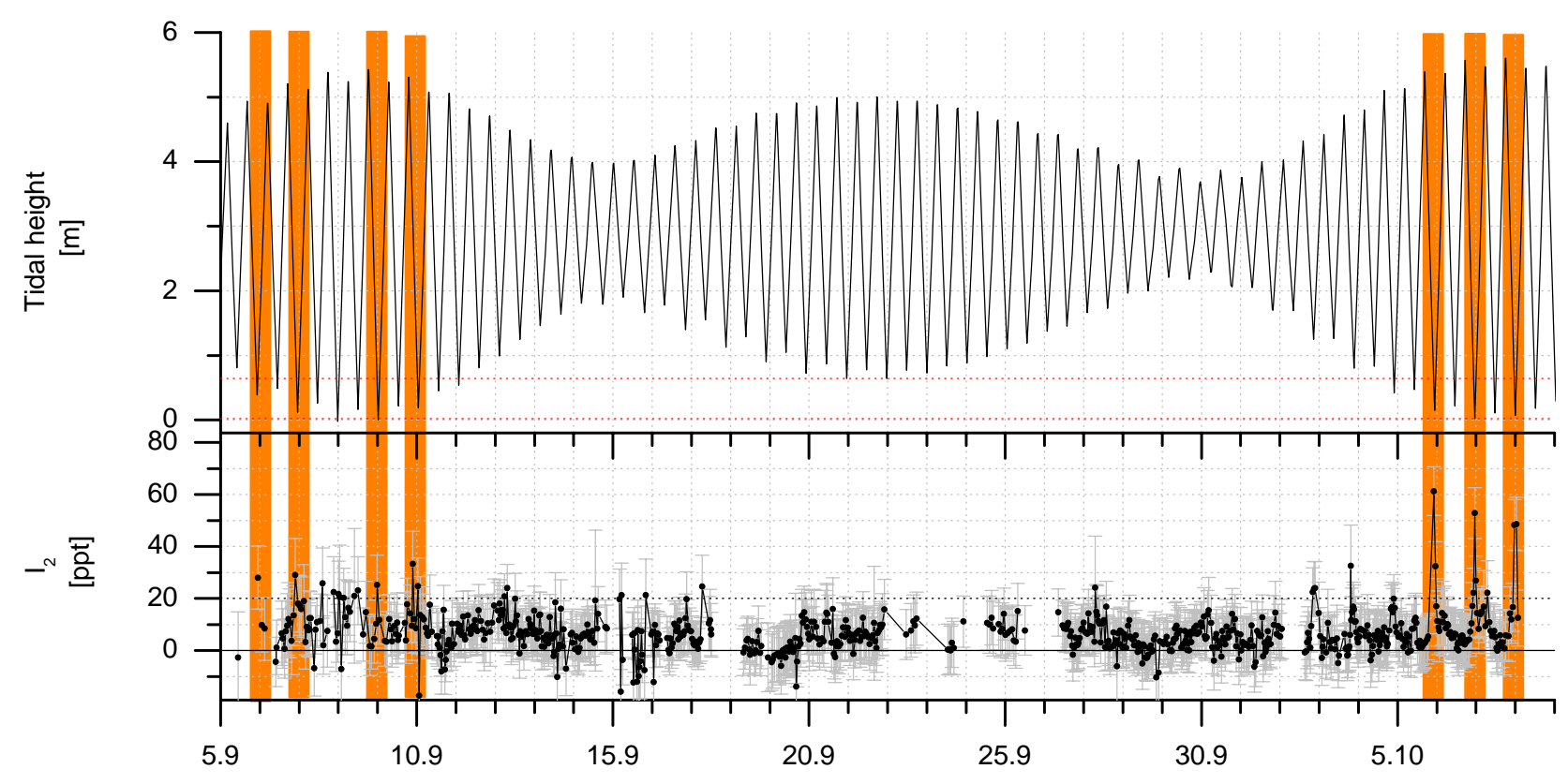

Fig. 13. $I_{2}$ time series of the Mace Head campaign in 1998. The dotted line indicates the mean detection limit of 20 ppt. The shaded areas indicate $\mathrm{I}_{2}$ clearly identified above the detection limit (with respect to the individual error).

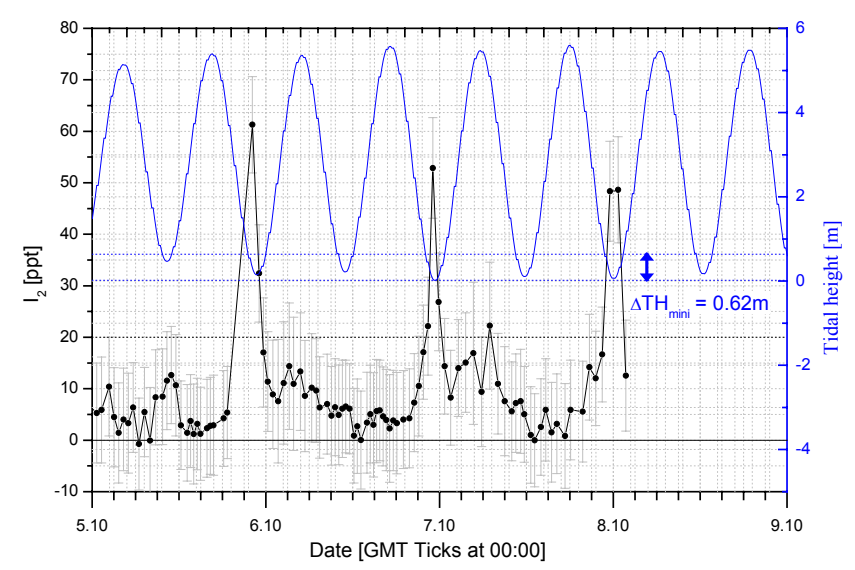

Fig. 14. 5, 6, and 7 October 1998 PARFORCE campaign in Mace Head, where the highest mixing ratios of up to $60 \mathrm{ppt} \mathrm{I}_{2}$ were detected.

assuming low tide from 11:00 a.m.-02:00 p.m.). Additional sensitivity studies are performed, assuming constant fluxes instead of constant mixing ratios of organoiodines in order to more realistically investigate the qualitative differences between the morning and midday scenarios (scenario 4). Furthermore, the effect of a hypothetical $\mathrm{I}_{2}$ flux on atmospheric chemistry is investigated (scenario 5).

\subsubsection{Model results}

Figure 16 shows the effect of prescribed organoiodine concentrations as measured in Brittany (see Table 5) on IO, BrO and ozone for scenarios assuming low tide during midday.
Table 5. Mixing ratios of organoiodines (ppt), as prescribed in the model scenarios. Values for scenarios 1-3 rely on mean or maximum mixing ratios, as measured in Brittany during "daytime" (05:00 a.m.-07:00 p.m.) or during "midday" (09:00 a.m.03:00 p.m.).

\begin{tabular}{lllllll}
\hline Scenario & $\mathrm{CH}_{3} \mathrm{I}$ & $\mathrm{C}_{2} \mathrm{H}_{5} \mathrm{I}$ & $\mathrm{C}_{3} \mathrm{H}_{7} \mathrm{I}$ & $\mathrm{CH}_{2} \mathrm{ClI}$ & $\mathrm{CH}_{2} \mathrm{BrI}$ & $\mathrm{CH}_{2} \mathrm{I}_{2}$ \\
\hline 0: none & 0 & 0 & 0 & 0 & 0 & 0 \\
1: daytime mean & 249 & 31.9 & 2.3 & 0.9 & 1.5 & 1.8 \\
2: midday max. & 542 & 9.1 & 23.5 & 2.9 & 7.8 & 5.4 \\
3: daytime max. & 1830 & 96.9 & 34.8 & 2.9 & 7.8 & 11.4 \\
\hline
\end{tabular}

After $3 \mathrm{~h}$ of low tide conditions IO mixing ratios reach about $1.5 \mathrm{ppt}, 4.5 \mathrm{ppt}$, and $10 \mathrm{ppt}$ in $15 \mathrm{~m}$ altitude for the different scenarios described above, which is in the range of the DOAS measurements (Fig. 16a). If exactly the same alkyl iodine concentrations are assumed for the morning hours, the modelled IO mixing ratios are about a factor of 4 lower (not shown). In all cases, the short-lived $\mathrm{CH}_{2} \mathrm{I}_{2}$ contributes by far the largest part to the modelled IO mixing ratios. For example, omitting the huge amount of $\mathrm{CH}_{3} \mathrm{I}(1830 \mathrm{ppt})$ in scenario 3 decreases IO by only $7 \%$ after $3 \mathrm{~h}$ at low tide. It should be noted that, compared to clean marine air with only a few ppt $\mathrm{NO}_{2}$ (as assumed by von Glasow et al., 2002b), a $\mathrm{NO}_{2}$ mixing ratio of about $1 \mathrm{ppb}$ (as used here) decreases the IO mixing ratios produced by a given amount of $\mathrm{CH}_{2} \mathrm{I}_{2}$ by roughly $50 \%$, primarily due to enhanced formation of $\mathrm{IONO}_{2}$. Recycling of reactive iodine by aerosol processing is responsible for roughly $10 \%$ of the modelled IO. 


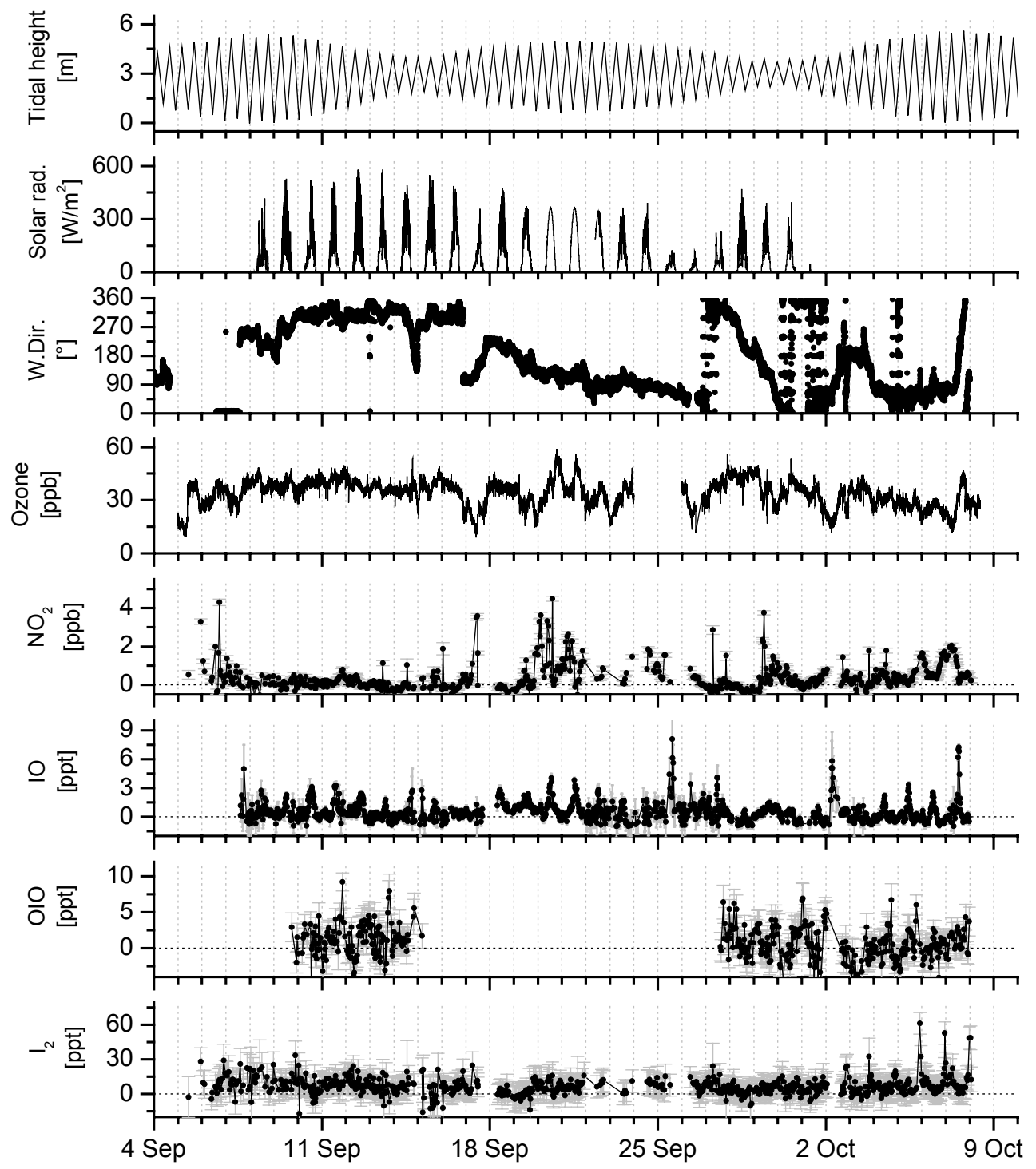

Date [GMT Tciks at 00:00]

Fig. 15. The time series for the campaign during 1998 PARFORCE campaign in Mace Head. Tidal height, meteorological parameters, and $\mathrm{NO}_{2}, \mathrm{I}_{2}, \mathrm{IO}, \mathrm{OIO}$ and $\mathrm{O}_{3}$ are shown.

The model-predicted $\mathrm{BrO}$ never exceeds $1 \mathrm{ppt}$, and thus ranges generally below the DOAS detection limit, in agreement with the measurements (Fig. 16b). Heterogeneous processing of $\mathrm{BrONO}_{2}$ accounts for about $20 \%$ of the modelled $\mathrm{BrO}$ mixing ratios. These $\mathrm{BrO}$ mixing ratios are lower than in the cases for the clean marine boundary layer, as discussed in von Glasow et al. (2002b), because of the high mixing ratio of $\mathrm{NO}_{\mathrm{x}}$ used here, which shifts the $\mathrm{BrO}$ vs. $\mathrm{BrONO}_{2}$ steady state mixing ratios. In our simulations, $\mathrm{BrO}$ significantly increases with increasing emissions of VHOCs. This increase is mainly due to the release of $\mathrm{Br}$ from the photolysis of $\mathrm{CH}_{2} \mathrm{BrI}$.
An important effect of organoiodine emissions is the destruction of ozone via photochemically produced I radicals. For the high organoiodine concentrations of scenario 3 , roughly $1 \mathrm{ppb}$ ozone is destroyed in $5 \mathrm{~h}$ (Fig. 16c), which is on the order of the natural variability of ozone, and therefore not detectable in the field, but relevant for atmospheric chemistry with typical ozone destruction rates of a few ppb per day.

The model runs depicted in Fig. 16 allow the direct comparison with measurements. To investigate the impact of photochemistry with constant fluxes of VHOCs (instead of prescribed concentrations), we did another set of model runs (Fig. 17). A constant surface flux of $4 \times 10^{9} \mathrm{molec} /\left(\mathrm{cm}^{2} \mathrm{~s}\right)$ of 

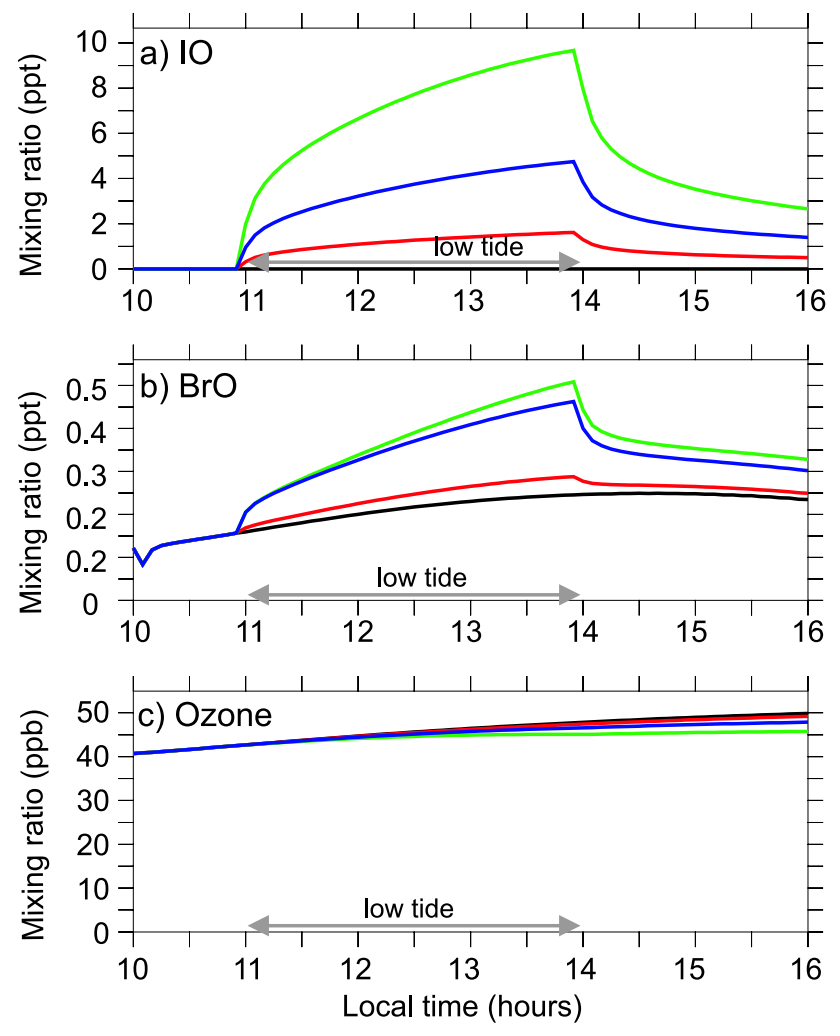

Fig. 16. Comparison of the model scenarios for midday hours. Different colors denote different prescribed mixing ratios of organoiodines, i.e., different scenarios (see Table 5): black - scenario 0 ; red - scenario 1 ; blue - scenario 2 ; green - scenario 3 . The period of low tide is marked on the time axis. Mixing ratios are shown for the lowest model layer $(5 \mathrm{~m})$.

$\mathrm{CH}_{2} \mathrm{I}_{2}$ (scenario 4) results in about $4 \mathrm{ppt} \mathrm{CH}_{2} \mathrm{I}_{2}$ at about $15 \mathrm{~m}$ altitude at midday, whereas $\mathrm{CH}_{2} \mathrm{I}_{2}$ mixing ratios reach up to $15 \mathrm{ppt}$ during the morning hours due to lower photolysis rates at higher zenith angles (Fig. 17a). For the same reason, I radical mixing ratios, and thus IO mixing ratios, are higher for the midday than for the morning scenario (green and black lines in Fig. 17c). After $3 \mathrm{~h}$ of emission during low tide, the ratio between midday and morning $\mathrm{IO}$ is about 2.3, which is in good qualitative agreement with the field measurements shown in Fig. 12.

Apart from scenarios assuming organoiodine emissions, Fig. 17 also shows otherwise identical scenarios prescribing a constant flux of molecular iodine $\left(10^{10} \mathrm{molec} /\left(\mathrm{cm}^{2} \mathrm{~s}\right)\right.$, scenario 5) instead of organoiodines (red and blue lines in Fig. 17). This leads to mixing ratios of $I_{2}$ in the model below $0.5 \mathrm{ppt}$ (Fig. 17b), the mixing ratios in the early morning being highest for the reason discussed above. Despite these low $\mathrm{I}_{2}$ mixing ratios, the effect on $\mathrm{IO}$ is considerable (Fig. 17c): After $3 \mathrm{~h}$ of emission during low tide, modelled IO mixing ratios rise to $8 \mathrm{ppt}$ in the morning, and $16 \mathrm{ppt}$ in the midday scenario. This is due to the short photolytic lifetime of about

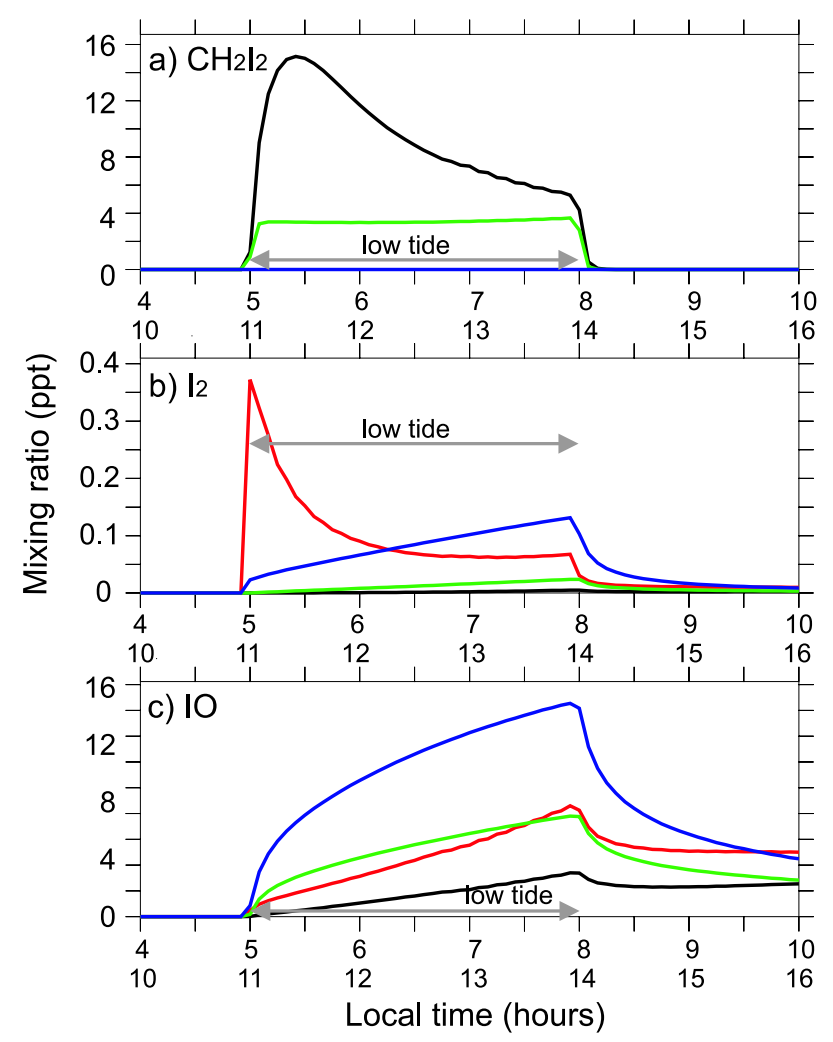

Fig. 17. Comparison of two morning and two midday scenarios assuming constant fluxes of organoiodines (scenario 4) or $\mathrm{I}_{2}$ (scenario 5), respectively: black - scenario 4 for morning hours; green - scenario 4 for midday hours; red - scenario 5 for morning hours; blue - scenario 5 for midday hours. Please note the different time axes for morning (04:00-10:00 a.m.) and midday (10:00 a.m.04:00 p.m.) scenarios. The period of low tide is marked. Mixing ratios are shown for the second model level $(15 \mathrm{~m})$.

$10 \mathrm{~s}$ for $\mathrm{I}_{2}$, compared to several minutes in the case of $\mathrm{CH}_{2} \mathrm{I}_{2}$. Hence, the model results confirm that even very low mixing ratios of $\mathrm{I}_{2}$ (well below the DOAS detection limit) can have a large impact on iodine chemistry.

The agreement of the model runs that include only VHOCs with the measured IO indicate that under the conditions encountered in Brittany, the presence of molecular iodine is not necessary to explain the observed IO mixing ratios. However, as we do not account for nucleation of iodine oxides, which could be an important sink for IO, we regard our model results as an upper limit of IO. Hence, in spite of the agreement between observations and modelling without including molecular iodine, we cannot exclude $\mathrm{I}_{2}$ as a precursor for IO. This conclusion is also supported by the fact that DOAS measurements yield mean mixing ratios along the light path and thus cannot identify hot spots. 


\section{Conclusions and outlook}

The measurements of RHS and their likely precursors at three different coastal environments, along with comparison to model studies, allows us to test whether our understanding of halogen chemistry, as represented in the model, is consistent with the data. The following conclusions can be drawn:

- We positively identified IO at levels of up to $7.7 \mathrm{ppt}$ as the only halogen oxide in all three studied coastal environments. The maximum level of IO consistently corresponded to the detected level of organoiodines found at the respective sites.

- BrO was not identified at any of the locations and we can confirm upper limits of its appearance in the respective MBL at 1.5-2 ppt, in agreement with our model calculations, even assuming contributions of observed biological sources as $\mathrm{CH}_{2} \mathrm{IBr}$ of up to 8 ppt.

- The agreement of our model calculations for the conditions of Brittany with the measurements is quite satisfactory: The IO mixing ratios observed by DOAS can be explained by the photolysis of observed levels of organoiodines alone. The presence of molecular iodine is not necessary to explain the observed IO mixing ratios but from the measurements its presence at levels below 20 ppt cannot be excluded.

- The impact of the presence of macroalgae on VHOCs was clearly demonstrated. Moreover, different types of macroalgae show individual emission patterns.

- OIO could not be identified unambiguously neither at the North Sea nor in Brittany. However, due to high detection limits in individual cases we cannot exclude the presence of OIO of up to 15 ppt. OIO at Mace Head was only clearly observed for short periods during two nights of the 1998 experiment, during other times OIO remained below the detection limit.

- No conclusions about the "hot spot" theory were possible due to the long lightpath of $\sim 10 \mathrm{~km}$ used for the DOAS measurements. The combination of spatially resolved OIO and IO measurements and particle bursts should be a topic of future field campaigns.

- $\mathrm{I}_{2}$ was found during the re-analysis of 1998 Mace Head data, with peak mixing ratios of up to $60 \mathrm{ppt}$ at night. The high levels were found to be closely correlated to exceptionally low water levels (spring-tide conditions), indicating macroalgae inhabiting the lowest part of the intertidal zone as the source. Significantly elevated levels of $I_{2}$ were not found at the comparable coastal site of Brittany. Further investigations and observations of the differences of these environments should be performed in order to estimate the global relevance of molecular iodine in the atmosphere.
- The biological state, e.g. the age of the macroalgae should be investigated, for example through longterm observations

- The current measurement technique has a relatively high detection limit for $\mathrm{I}_{2}$, and the model studies suggest that even very low mixing ratios of $\mathrm{I}_{2}$ under daylight conditions could strongly affect the marine atmosphere.

Acknowledgements. We would like to thank the BMBF for funding the ReHaTrop project in the framework of the AFO2000 program. For fruitful discussions on halogen chemistry we would like to thank R. von Glasow. For encouraging support during the extended field campaigns much thanks to A. Lotter, O. Sebastián, R. Sinreich, S. Laukemann and very special thanks to N. Bobrowski.

Edited by: A. Richter

\section{References}

Alicke, B., Hebestreit, K., Stutz, J., and Platt, U.: Iodine oxide in the marine boundary layer, Nature, 397, 572-573, 1999.

Allan, B. J., McFiggans, G., and Plane, J. M. C.: Observation of iodine monoxide in the remote marine boundary layer, J. Geophys. Res., 105, 14 363-14 369, 2000.

Allan, B. J., Plane, J. M. C., and McFiggans, G.: Observations of OIO in the remote marine boundary layer, Geophys. Res. Lett., 28, 1945-1948, 2001.

Atkinson, R., Baulch, D. L., Cox, R. A., Crowley, J., Hampson Jr., R. F., Hynes, R., Jenkin, M., Kerr, J. A., Rossi, M. J., and Troe, J.: Summary of Evaluated Kinetic and Photochemical Data for Atmospheric Chemistry: Web Version July 2004, http://www. iupac-kinetic.ch.cam.ac.uk, 2004.

Bloss, W. J., Rowley, D. M., Cox, R. A., and Jones, R. L.: Kinetics and Products of the IO Self-Reaction, J. Phys. Chem. A, 105, 7840-7854, 2001.

Bobrowski, N., Hönninger, G., Galle, B., and Platt, U.: Detection of bromine monoxide in a volcanic plume, Nature, 423, 273-276, 2003.

Burkholder, J. B., Curtius, J., Ravishankara, A. R., and Lovejoy, E. R.: Laboratory studies of the homogeneous nucleation of iodine oxides, Atmos. Chem. Phys., 4, 19-34, 2004, SRef-ID: 1680-7324/acp/2004-4-19.

Carpenter, L., Hebestreit, K., Sturges, W., Penkett, S., Liss, P., Alicke, B., and Platt, U.: Observation of short-lived alkyl iodides and bromides at Mace Head, Ireland: links to biogenic sources and halogen oxide production, J. Geophys. Res., 104, 16791689, 1999.

Carpenter, L., Liss, P., Platt, U., and Hebestreit, K.: Coastal zone production of IO precursors: a 2-dimensional study, Atmos. Chem. Phys., 1, 9-17, 2001,

SRef-ID: 1680-7324/acp/2001-1-9.

Carpenter, L. J.: Iodine in the marine boundary layer, Chem. Rev., 103, 4953-4962, 2003.

Coheur, P.-F., Fally, S., Carleer, M., Clerbaux, C., Colin, R., Jenouvrier, A., Mérienne, M.-F., Hermans, C., and Vandaele, A. C.: New water vapor line parameters in the $26000-13000 \mathrm{~cm}^{-1}$ region, J. Quant. Spect. Rad. Trans., 74, 493-510, 2002. 
Cox, R., Bloss, W., Jones, R., and Rowley, D.: OIO and the atmospheric cycle of iodine, Geophys. Res. Lett., 26, 1857-1860, 1999.

Ekdahl, A., Pedersen, M., and Abrahamsson, K.: A study of the diurnal variation of biogenic volatile halocarbons, Mar. Chem., 63, 1-8, 1998.

Fayt, C. and van Rozendael, M.: WinDOAS, ISAB/BIRA Belgium, http://www.oma.be/BIRA-IASB, 2001.

Frieß, U.: Spectroscopic Measurements of Atmospheric Trace Gases at Neumayer-Station, Antarctica, Institut für Umweltphysik, Universität Heidelberg, PhD thesis, 2001.

Frieß, U., Wagner, T., Pundt, I., Pfeilsticker, K., and Platt, U.: Spectroscopic Measurements of Tropospheric Iodine Oxide at Neumeyer Station, Antarctica, Geophys. Res. Lett., 28, 19411944, 2001.

Greenblatt, G. D., Orlando, J. J., Burkholder, J. B., and Ravishankara, A. R.: Absorption Measurements of Oxygen between 330 and 1140 nm, J. Geophys. Res., 95, 18 577-18 582, 1990.

Hausmann, M. and Platt, U.: Spectroscopic measurement of bromine oxide and ozone in the high Arctic during Polar Sunrise Experiments 1992, J. Geophys. Res., 99, 25 399-25 413, 1994.

Hebestreit, K.: Halogen Oxides in the Mid-Latitudinal Planetary Boundary Layer, Institut für Umweltphysik, Universität Heidelberg, PhD thesis, 2001.

Hebestreit, K., Stutz, J., Rosen, D., Matveiv, V., Peleg, M., Luria, M., and Platt, U.: DOAS Measurements of Tropospheric Bromine Oxide in Mid-Latitudes, Science, 283, 55-57, 1999.

Hegels, E., Crutzen, P. J., Klüpfel, T., Perner, D., and Burrows, P. J.: Global distribution of atmospheric bromine monoxide from GOME on earth-observing satellite ERS 2, Geophys. Res. Lett., 25, 3127-3130, 1998.

Hoffmann, T., O’Dowd, C. D., and Seinfeld, J. H.: IO homogeneous nucleation: An explanation for coastal new particle formation, Geophys. Res. Lett., 28, 1949-1952, 2001.

Hönninger, G.: Referenzspektren reaktiver Halogenverbindungen für DOAS-Messungen, University of Heidelberg, Diploma thesis, 1999.

Hönninger, G.: Halogen Oxide Studies in the Boundary Layer by Multi Axis Differential Optical Absorption Spectroscopy and Active Longpath-DOAS, Institut für Umweltphysik, Universität Heidelberg, PhD thesis, 2002.

Hönninger, G., Bobrowski, N., Palenque, E., Torrez, R., and Platt, U.: Reactive bromine and sulfur emissions at Salar de Uyuni, Bolivia, Geophys. Res. Lett., 31, L04101, doi:10.1029/2003GL018818, 2004a.

Hönninger, G., Leser, H., Sebastián, O., and Platt, U.: Groundbased measurements of halogen oxides at the Hudson Bay by active longpath DOAS and passive MAX-DOAS, Geophys. Res. Lett., 31, L04111, doi:10.1029/2003GL018982, $2004 b$

Jimenez, J. L., Bahreini, R., Cocker, D. R., Zhuang, H., Varutbangkul, V., Flagan, R. C., Seinfeld, J. H., O’Dowd, C. D., and Hoffmann, T.: New particle formation from photooxidation of diiodomethane $\mathrm{CH}_{2} \mathrm{I}_{2}$, J. Geophys. Res., 108, 4318, doi:10.1029/2002JD002452, 2003.

Leser, H., Hönninger, G., and Platt, U.: MAX-DOAS measurements of $\mathrm{BrO}$ and $\mathrm{NO}_{2}$ in the marine boundary layer, Geophys. Res. Lett., 30, 1537, doi:10.1029/2002GL015811, 2003.

Mäkelä, J. M., Hoffmann, T., Holzke, C., Väkevä, M., Suni, T., Mat- tila, T., Aalto, P. P., Tapper, U., Kauppinen, E. I., and O’Dowd, C. D.: Biogenic iodine emissions and identification of endproducts in coastal ultrafine particles during nucleation bursts, J. Geophys. Res., 107, 8110, doi:10.1029/2001JD000580, 2002.

Martinez, M., Arnold, T., and Perner, D.: The role of bromine and chlorine chemistry for Arctic ozone depletion events in $\mathrm{Ny}$ Ålesund and comparison with model calculations, Ann. Geophys., 17, 941-956, 1999,

SRef-ID: 1432-0576/ag/1999-17-941.

Matveev, V., Peleg, M., Rosen, D., Tov-Alper, D. S., Hebestreit, K., Stutz, J., Platt, U., Blake, D., and Luria, M.: Bromine oxide - ozone interaction over the Dead Sea, J. Geophys. Res., 106, 10375-10387, 2001.

Meller, R. and Moortgat, G. K.: Temperature dependance of the absorption cross sections of $\mathrm{HCHO}$ between 223 and $323 \mathrm{~K}$ in the wavelength range $225-375 \mathrm{~nm}$, J. Geophys. Res., 105, 7089 7102, 2000.

Mössinger, J., Shallcross, D., and Cox, R.: UV-VIS absorption cross-section and atmospheric lifetimes of $\mathrm{CH}_{2} \mathrm{Br}_{2}, \mathrm{CH}_{2} \mathrm{I}_{2}$ and $\mathrm{CH}_{2}$ BrI, J. Chem. Soc. Faraday Trans., 94 (10), 1391-1396, 1998.

O’Dowd, C., Geever, M., Hill, M., Smith, M., and Jennings, S.: New particle formation: nucleation rates and spatial scales in the clean marine coastal environment, Geophys. Res. Lett., 25, 1661-1664, 1998.

O’Dowd, C., Jimenez, J., Bahreini, R., Flagan, R. C., Seinfeld, J., Haemeri, K., Pirjola, L., Kulmala, M., Jennings, S., and Hoffmann, T.: Marine aerosol formation from biogenic iodine emissions, Nature, 417, 632-636, 2002.

Platt, U.: Differential optical absorption spectroscopy (DOAS), in: Air Monitoring by Spectroscopic Techniques, edited by: Sigrist, W. M., John Wiley \& Sons, Inc., 127, 27-84, 1994.

Platt, U. and Hönninger, G.: The role of halogen species in the troposphere, Chemosphere, 52, 325-338, 2003.

Platt, U. and Lehrer, E.: Arctic Tropospheric Ozone Chemistry, ARCTOC, Final Report of the EU-Project No. EV5V-CT930318, Heidelberg, 1996.

Platt, U. and Perner, D.: Measurements of Atmospheric Trace Gases by Long Path Differential UV/visible Absorption Spectroscopy, Optical and Laser Remote Sensing, p. 95-105, Springer Verlag, New York, 1983.

Pruvost, J.: Étude des composés organiques halogénés volatils en milieu marin. Origines biologiques et anthropiques, échanges avec l'atmosphère - Utilisation comme traceurs transitoires de la circulation dans l'Atlantique de Nord-Est, DEA Chimie fine, Chimie Analytique, Chimie de l'Environnement Marin de l'Université de Bretagne Occidentale, PhD thesis, 2001.

Saiz-Lopez, A. and Plane, J.: Novel iodine chemistry in the marine boundary layer, Geophys. Res. Lett., 31, L04112, doi:10.1029/2003GL019215, 2004.

Saiz-Lopez, A., Plane, J. M. C., and Shillito, J. A.: Bromine oxide in the mid-latitude marine boundary layer, Geophys. Res. Lett., 31, doi:10.1029/2003GL018956, 2004a.

Saiz-Lopez, A., Saunders, R. W., Joseph, D. M., Ashworth, S. H., and Plane, J. M. C.: Absolute absorption cross-section and photolysis rate of $\mathrm{I}_{2}$, Atmos. Chem. Phys., 4, 1443-1450, 2004b, SRef-ID: 1680-7324/acp/2004-4-1443.

Sander, R., Keene, W. C., Pszenny, A. A. P., Arimoto, R., Ayers, G. P., Baboukas, E., Cainey, J. M., Crutzen, P. J., Duce, R. A., 
Hönninger, G., Huebert, B. J., Maenhaut, W., Mihalopoulos, N., Turekian, V. C., and Van Dingenen, R.: Inorganic bromine in the marine boundary layer: a critical review, Atmos. Chem. Phys., 3 , 1301-1336, 2003,

SRef-ID: 1680-7324/acp/2003-3-1301.

Schall, C. and Heumann, K. G.: GC determination of volatile organoiodine and organobromine compounds in Arctic seawater and air samples, Fresenius' Journal of Analytical Chemistry, 346, 717-22, 1993.

Schall, C., Laturnus, F., and Heumann, K. G.: Biogenic volatile organoiodine and organobromine compounds released from polar macroalgae, Chemosphere, 28, 1315-1324, 1994.

Schwarz, A. and Heumann, K.: Two-dimensional on-line detection of brominated and iodinated volatile organic compounds by ECD and ICP-MS after GC separation, Anal. and Bioanalytical Chem., 374, 212-219, 2002.

Sebastián, O.: The relative contribution of free radicals to the oxidation chain of Dimethylsulphide in the marine boundary layer, Institut für Umweltphysik, Universität Heidelberg, $\mathrm{PhD}$ thesis, 2004.

Stutz, J.: Messung der Konzentration troposhärischer Spurenstoffe mittels Differentieller Optischer Absorptions Spektroskopie: Eine neue Generation von Geräten und Algorithmen, Institut für Umweltphysik, Universität Heidelberg, PhD thesis, 1996.

Stutz, J. and Platt, U.: Numerical Analysis and Estimation of the Statistical Error of Differential Optical Absorption Spectroscopy Measurements with Least-Squares methods, Appl. Opt., 35, 6041-6053, 1996.

Stutz, J., Ackermann, R., Fast, J. D., and Barrie, L.: Atmospheric reactive chlorine and bromine at the Great Salt Lake, Utah, Geophys. Res. Lett., 29, doi:10.1029/2002GL014812, 2002.

Tuckermann, M., Ackermann, R., Gölz, C., Lorenzen-Schmidt, H., Senne, T., Stutz, J., Trost, B., Unold, W., and Platt, U.: DOASobservation of halogen radical - catalysed Arctic boundary layer ozone destruction during the ARCTOC campaign 1995 and 1996 in Ny-Alesund, Spitsbergen, Tellus, 49b, 533-555, 1997.
Voigt, S., Orphal, J., and Burrows, J. P.: The temperature dependence $(203-293 \mathrm{~K})$ of the absorption cross sections of $\mathrm{O}_{3}$ in the $230-850 \mathrm{~nm}$ region measured by Fourier-transform spectroscopy, J. Photochem. Photobiol., 143, 1-9, 2001.

Voigt, S., Orphal, J., and Burrows, J. P.: The temperature and pressure dependence of the absorption cross-sections of $\mathrm{NO}_{2}$ in the $250-800 \mathrm{~nm}$ region measured by Fourier-transform spectroscopy, J. Photochem. Photobiol., 149, 1-7, 2002.

von Glasow, R. and Sander, R.: Variation of sea salt aerosol pH with relative humidity, Geophys. Res. Lett., 28, 247-250, 2001.

von Glasow, R., Sander, R., Bott, A., and Crutzen, P. J.: Modeling halogen chemistry in the marine boundary layer 2. Interactions with sulfur and the cloud-covered MBL, J. Geophys. Res., 107, 4323, doi:10.1029/2001JD000943, 2002a.

von Glasow, R., Sander, R., Bott, A., and Crutzen, P. J.: Modeling halogen chemistry in the marine boundary layer 1 . Cloud-free MBL, J. Geophys. Res., 107, 4341, doi:10.1029/2001JD000942, 2002 b.

Wagner, T., Leue, C., Wenig, M., Pfeilsticker, K., and Platt, U.: Spatial and temporal distribution of enhanced boundary layer $\mathrm{BrO}$ concentrations measured by the GOME instrument aboard ERS2, J. Geophys. Res., 106, 24 225-24 235, 2001.

Wilmouth, D. M., Hanisco, T. F., Donahue, N. M., and Anderson, J. G.: Fourier Transform Ultraviolet Spectroscopy of the A 2P3/2 X 2P3/2 Transition of BrO, J. Phys. Chem. A, 103, 8935-8945, 1999.

Wittrock, F., Müller, R., Richter, A., Bovensmann, H., and Burrows, J. P.: Measurements of iodine monoxide (IO) above Spitsbergen, Geophys. Res. Lett., 27, 1471-1474, 2000.

Zingler, J. and Platt, U.: Iodine oxide in the Dead Sea valley: Evidence for inorganic sources of boundary layer IO, J. Geophys. Res., 110, D07307, doi:10.1029/2004JD004993, 2005. 